ISSN: 2146-3042

DOI: $10.25095 /$ mufad.899318

\title{
Muhasebe Alanında Yayımlanan Seçilmiş Beş Dergide 2016-2020 Yılları Arasında Denetim Konusunda Yayımlanmıș Makalelerin Bibliyometrik Analizi*
}

\author{
Erdoğan CEYLAN**
}

\section{ÖZET}

Bu çalışmanın amacı, Türkiye'de muhasebe alanında yayımlanmakta olan seçilmiş beş dergide 20162020 yılları arasında denetim konusunda yayımlanmış makalelerin bibliyometrik analizinin yapılmasıdır. Araştırma kapsamında, seçilen dergilerin elektronik basımlarından 143 makaleye ulaşılmıştır. Araştırmada nitel araştırma yöntemlerinden bibliyometrik analiz yöntemi kullanılmıştır. Ulaşılan makaleler içerik analizi yöntemiyle sayısal verilere dönüstürü̈lmüs, Microsoft Excel programına aktarllmış ve bu program aracıllğı ile analize tabi tutulmuştur. Çalışma sonucunda tespit edilen temel bulgular şöyledir: En fazla yayının Muhasebe Bilim Dünyası Dergisi'nde ve en fazla çalışmanın 2018 yllında yayımlandı̆̆ı, en çok nicel araştırma yöntemlerinin kullanıldı̆̆g, erkek yazarların çalı̧̧malara daha çok katkl yaptı̆̆l, iki yazarlı çalışmaların daha çok olduğu, en sık çalışılan denetim alt konusunun "iç denetim" olduğu, çalışmalarda yabancı kaynaklara daha fazla başvurulduğu tespit edilmişstir. Ayrıca, Muhasebe ve Finansman Dergisi'ndeki yayınların, teorik çalışmaların, tek yazarlı çalışmaların ve kilit denetim konusunun yayın başına en fazla atıf alan çalışmalar olduğu belirlenmiştir.

Anahtar Kelimeler: Muhasebe Alan Dergileri, Denetim, Bibliyometrik Analiz, Attf Analizi.

JEL Sinıflandirması: M40, M42, I20.

Bibliometric Analysis of Articles Published on Audit Between 2016-2020 in Five Selected Journals Published in the Field of Accounting

\section{ABSTRACT}

The aim of this study is to conduct a bibliometric analysis of the articles published on auditing between 2016-2020 in five selected journals in the field of accounting. Within the scope of the research, 143 articles were reached from the electronic editions of selected journals. In the study was used the bibliometric analysis method that one of the qualitative research methods. The obtained articles were transformed into numerical data with the method of content analysis, transferred to Microsoft Excel and analyzed by means of this program. The basic findings determined as a result of the study are as follows: It has been determined that the highest number of publications were published in the Journal of Accounting Science World and the most studies were published in 2018, the most quantitative research methods were used, male authors contributed more to the studies, and there were more studies with two authors, the most studied audit sub-topic is "internal audit" and foreign sources are used more frequently in the studies. In addition, it has been determined that in the the publications Journal of Accounting and Finance theoretical studies, single author studies and key audit subject are the most cited studies per publication.

Keywords: Accounting Field Journals, Auditing, Bibliometric Analysis, Citation Analysis.

Jel Classification: M40, M42, I20.

\footnotetext{
* Makale Gönderim Tarihi: 20.03.2021, Makale Kabul Tarihi: 27.04.2021 , Makale Türü: Nitel Araştırma ** Öğr. Gör. Dr., Bilecik Şeyh Edebali Üniversitesi, Gölpazarı Meslek Yüksekokulu erdogan.ceylan@bilecik.edu.tr, ORCID: 0000-0001-6890-9673.
} 


\section{GİRIŞ}

Geçmişten günümüze değin hata, hile ve suistimale bağlı birçok finansal yolsuzluk meydana gelmiş ve denetim düşüncesi bu olaylarla birlikte önem kazanmış ve gelişmiştir. Denetçi deyimi ilk olarak 1289 yılında kullanılmaya başlanmış, muhasebe denetçilerinin ilk örgütlenmesi 1581 'de Venedik'te oluşmuş, ilk denetim firması 1845 'te W. Deloitte tarafindan Londra'da kurulmuş, şirketlerde ilk zorunlu denetim 1900 y1lında İngiltere'de başlamış ve Amerika Birleşik Devletleri'nde (ABD) denetlenmiş ilk mali tablo 1901 yllında yayımlanmıştır (Uzay vd. 2009: 128). Dünyada sanayi ve ticaret alanında yaşanan gelişmelere paralel olarak muhasebe denetimi anlayışında da değişiklikler yaşanmış denetime iliş̧in taraflar zamanla genişlemiş ve farklılaşmıştır (Güredin, 2010: 14). Bu günkü anlamda muhasebe denetimi, 1930'lu yıllardan itibaren, mali tablolara bir bütün olarak genel bir güvenilirlik görüşü oluşturma amacıyla gözlem, örnekleme ve matematiksel hesaplamalara dayalı denetim şeklinde başlamış (Bozkurt, 2012: 18) ve bugün yerini çeşitli bilgi teknolojileri aracılığı yapılan denetimlere bırakmıştır. Ayrıca, 2000'li yılların başında Enron, Worldcom ve Parmalat'n da aralarında bulunduğu birçok global şirkette yaşanan finansal skandallar, Sarbanes- Oxley Yasası, Statements on Auditing Standarts (SAS) No: 99, International Standards on Auditing (ISA) No: 240, Avrupa Birliği 2006/43/EC Say1l Yönerge ve Türkiye'de Seri: X No: 22 sayılı Sermaye Piyasası Kurulu Tebliği olmak üzere, denetim alanında ulusal ve uluslararası yasal düzenlemelerin başlıca temelini oluşturmuştur. $\mathrm{Bu}$ düzenlemeler hata ve hileyi ortaya çıkarmaya ve hileli işlemlerin varlığını dikkate almaya yönelik anlayış ortaya koymuş ve/veya var olan anlayışı geliştirmiştir.

Tarih boyunca yaşanan tecrübelere bağlı olarak, finansal tablo kullanıcılarının, işletme yönetimi tarafindan hazırlanan ve yanıltıcı bilgi olma olasılığı bulunan finansal ve finansal olmayan verilere güvenmesi ve karar alması oldukça zordur (Fidan, 2019: 1). Finansal raporlardaki bilgilerin güvenilirlikten uzak olması ekonomik yapı için de son derece önemli olup güvenilir olmayan finansal bilgiler sermaye piyasalarının gelişimine engel olmaktadır (Başpınar, 2005: 37). Bu bakımdan finansal bilgilerin tam ve doğru raporlanmasının yanı sıra bu bilgilerin güvenilirliğini ortaya koyan denetim de her daim önemli görülmüştür. $\mathrm{Bu}$ sebeple denetim faaliyetleri ve denetimin raporlanması üzerine ihtiyaca uygun olarak sürekli yenilikler ve güncellemeler yapılmış ve bundan sonra da sıkça yapılmaya devam edileceği şüphesizdir. Bu bağlamda, sürekli güncellenmekte olan konular denetim alanında yapılan bilimsel çalışmalara da yön vermekte ve bu çalışmalarla uygulayıcılara rehber olunmaya çalışılmaktadır. $\mathrm{Bu}$ çalışmada temel olarak denetim alanında güncel konuların belirlenmesi ve bu çalışmaların içeriklerinin analiz edilmesi amaçlanmıştır.

\section{LITERATÜR}

Araştırma bibliyometrik analiz yöntemi ile gerçekleştirilmiştir. Literatürde bu yöntemle yapılan ilk çalışmanın kim tarafından yapıldığı konusunda iki farklı bilgi bulunmaktadır. Al (2008)'e göre bu yöntemle yapılan ilk çalışma 1896'da Campbell tarafından bibliyografi alanında yapılan araştırmadır. Akgün ve Karataş (2017)'a göre ise Cole ve Eales tarafından 1917 yılında anatomi alanında yapılan araştırma bibliyometrik analiz yöntemiyle yapılan ilk çalışma olup literatürde de bu analiz yöntemiyle yapılmış ilk çalışma olduğu konusunda genel kabul bulunmaktadır. Bu çalışma dışında uluslararası alanda, 
Hulme'nin (1923) tarih bilimi alanında yaptığı araştırma (Akgün ve Karataş, 2017: 21), Gross ve Gross'un (1927) ABD'de bir kimya dergisinin kaynakçalarını değerlendirdiği ve atıf analizlerini yaptığ 1 çalışma bibliyometrik analiz çalışmalarının öncülerindendir (Polat vd., 2013: 275). Türkiye'de bu yöntemle yapılan ilk çalışma ise Kemal Özinönü tarafından 1970 yılında yayımlanan 1933-1966 yılları arasında temel bilimlerdeki bilimsel verimliliği ölçen "Growth in Turkish Positive Basic Sciences" adlı araştırmadır. Türkiye'de bu analiz kullanılarak yapılan çalışmaların yakın geçmişte oldukça önem kazandığ 1 yapılan çalışma sayısının artmasıyla anlaşılmaktadır. Muhasebe alanında da son yıllarda bu araştırmaların arttığı görülmekte olup yapılan çalışmaların bazıları şöyledir: Sakin (2008) İşletme Fakültesi Dergisi'nde 1972-2007 yılları arasında yayımlanan muhasebe alanındaki çalışmaları, Uysal (2009) Muhasebe Bilim Dünyası Dergisi'nde 2004-2006 yılları arasında yayımlanan makaleleri, Önce ve Başar (2010) 2000-2008 yılları arasında muhasebe alanında yazılmış çalışmaları, Hotamışlı ve Erem (2014) Muhasebe ve Finansman Dergisi'nde 2005-2013 yılları arasında yayımlanan makaleleri, Apak, Erol ve Öztürk (2016) Muhasebe ve Finans Tarihi Araştırmaları Dergisi'nde 2011-2016 yılları arasında yayımlanan makaleleri, Akgün ve Karataş (2017) Muhasebe ve Denetime Bakış Dergisi'nde 2000- 2016 yılları arasında yayımlanan makaleleri inceleyerek analiz etmişlerdir.

Türkiye'de denetim alanında yapılmış olan bibliyometrik araştırmaların bazıları ise şöyledir: Selimoğlu ve Uzay (2007)'de Türkiye'de denetim alanında 1995-2005 yılları arasında yapılan akademik çalışmaları, Kuruçay ve Serçemeli (2018)'de Türkiye'de hile denetimi alanında 2008-2017 yılları arasında bilimsel dergilerde yayımlanmış makaleleri, Ceylan (2019)'da Türkiye'de hile denetimi alanında 2009-2018 yılları arasında yayımlanmış çalışmaları, Kaya (2019)'da Türkiye'de denetim alanında 1995-2018 yılları arasında tamamlanmış olan doktora tezlerini ve Parlak (2020)'de Türkiye'de denetim alanında 19842019 yılları arasında tamamlanmış olan lisansüstü tezleri incelemiştir.

\section{METODOLOJI}

\subsection{Amaç ve Kapsam}

Bu çalışmada, Türkiye'de muhasebe alanında yayımlanmakta olan dergilerde 20162020 yılları arasında denetim konusunda yayımlanmış makalelerin bibliyometrik analizinin yapılması amaçlanmıştır. Bu amaç doğrultusunda araştırma kapsamı için öncelikle muhasebe alanında TR Dizin'de yer alan ve 2016 yılından bu yana yayımlanmakta olan dergiler incelenmiştir. Bu kapsamda "Muhasebe ve Finansman Dergisi (MUFAD)", "Muhasebe Bilim Dünyası Dergisi (MODAV)", "Muhasebe ve Denetime Bakış Dergisi (MDB)" ve "Muhasebe ve Vergi Uygulamaları Dergisi (MUVU)" olmak üzere toplam dört derginin bu şartlara uygun olduğu görülmüştür. Sayılan dergiler dışında Türkiye'de muhasebe meslek odaları tarafından yayımlanan dergiler araştırılmıştır. Bu dergiler arasında İstanbul, İzmir ve Balıkesir Mali Müşavirler Odaları ile İzmir Yeminli Mali Müşavirler Odası'nın yayımladığı dergiler arasında yalnızca İstanbul Serbest Muhasebeci Mali Müşavirler Odası'nın yayımladığı "Mali Çözüm Dergisi (MÇ)” nin 2016 yılından buyana yayımlanmakta olduğu tespit edilmiştir. Bu sebeple TR Dizin'de yer alan dört dergi dışında Mali Çözüm Dergisi de araştırma kapsamına dahil edilerek çalışmada toplam beş dergi incelenmiştir.

Araştırma kapsamındaki dergilerin tamamı uluslararası hakemli dergi olma özelliğini taşımaktadır. MUFAD, "Muhasebe ve Finansman Öğretim Üyeleri Derneği” bünyesinde, 
MODAV ise, "Muhasebe Öğretim Üyeleri Bilim ve Dayanışma Vakfı" bünyesinde, 1999 yılında yayımlanmaya başlamıştır. Her iki dergi üçer aylık periyotlarla yılda dört sayı yayımlamaktadır. MDB, "Türkiye Serbest Muhasebeci Mali Müşavirler ve Yeminli Mali Müşavirler Odaları Birliği” bünyesinde 2000 yılında yayımlanmaya başlamıştır. Dergi dörder aylık periyotlarla yılda üç sayı yayımlamaktadır. MUVU, "Ankara Serbest Muhasebeci Mali Müşavirler Odası" bünyesinde 2008 yılında yayımlanmaya başlamıştır. Dergi dörder aylık periyotlarla yılda üç sayı yayımlamaktadır. MÇ, "İstanbul Serbest Muhasebeci Mali Müşavirler Odası" bünyesinde 1991 yılında yayımlanmaya başlamıştır. Dergi ikişer aylık periyotlarla yılda altı sayı yayımlamaktadır. Araştırma "denetim" konusunda yapılan çalışmalarla sınırlı tutulmuştur. Bu kapsamda sayılan dergilerin elektronik basımlarından denetim konusunda yayımlanmış 143 makaleye ulaşılmıştır.

\subsection{Araştırma Problemi}

$\mathrm{Bu}$ araştırma ile, muhasebe alanında son yıllarda denetim konusu ile ilgili yapılan bilimsel çalışmaların durumu, hangi alt konuların daha çok ele alınarak incelendiği, denetim alanına ilişkin çalışmaların hangi dergilerde daha sık yayımlandığı, hangi araştırma yöntemlerinin tercih edildiği, çalışmalarda cinsiyet ve yazar sayısı ilişkisinin ne olduğu gibi soruların yanı sıra yayımlanan makalelerde hangi kriterlerin atıf sayısında etkili olduğu diğer bir ifadeyle hangi çalışmaların daha çok atıf aldığı sorularının yanıtı bulunmaya çalışılmıştır.

\subsection{Yöntem}

Araştırma yöntemi, nitel araştırma yöntemlerinden bibliyometrik analiz yöntemidir. Bibliyometrik analiz, "matematiksel ve istatistiksel tekniklerle, çeşitli dergi, kitap ve benzeri organlarda yayımlanmış bilimsel çalışmaların incelenmesi tekniğidir (Pritchard, 1969: 348). $\mathrm{Bu}$ analiz yöntemi bilimsel amaçla yayımlanan dergilerin içeriklerinin analiz edilmesi için başvurulan en yaygın tekniktir (Akgün ve Karataş, 2017: 20). Bibliyometrik analiz, tanımlayıcı istatistiksel nitelikte (örneğin, yıl/makale sayısı) veya bir eserin etkinliğinin değerlendirilmesi (atıfların analiz edilmesi) gibi farklı biçimde olabilir (McBurney ve Novak, 2002: 109). Araştırma kapsamında ulaşılan 143 makale içerik analizi yöntemiyle sayısal verilere dönüştürülmüş, Microsoft Excel programına aktarılmış ve bu program aracıllğı ile tanımlayıcı istatistiksel analizler ve atıf etkinlik analizi yapılmıştır.

\subsection{Araştırma Bulguları}

Araştırma kapsamında ulaşılan 143 makale, yayımlandığ 1 yıl, yayımlandığı dergi, yazar(lar), yayın başlığı, yayın türü, araştırma türü ve yöntemi, çalışmanın ana teması ve konusu, araştırma kapsamı, araştırma sonucu, kaynak sayısı ve atıf sayısı dikkate alınarak içerik analizine tabi tutulmuştur. Araştırma kapsamı, araş̧ırma teknik ve yöntemleri ile araştırma sonuçlarına ilişkin verilerin uzun olması ve tabloya sığmaması nedeniyle bu bilgiler dışındaki sayılan diğer veriler EK 1'de yer alan tabloda gösterilmiştir.

EK 1'de yer alan tablo yardımıla yapılan içerik analizinden elde edilen bilgilerle öncelikle tanımlayıcı istatistiksel nitelikteki analizlere, devamında yayınların atıf verimliliğine ilişkin bulgulara yer verilmiştir. Sonuçlar öncelikle şekil/tablo halinde verilmiş daha sonra verilere ilişkin açıklamalar yapılmıştır. 


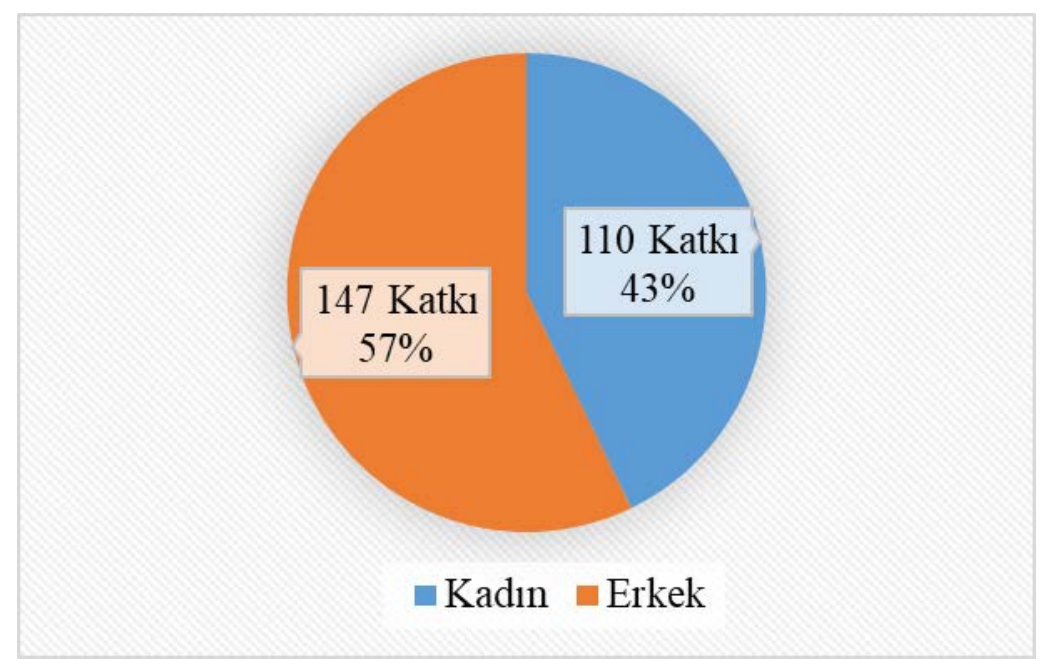

Şekil 1. Yayınlara Katkı Sunan Yazarların Cinsiyet Dağılımı

Şekil 1'de yayımlanan dergilere katkı sağlayan yazarların cinsiyet dağılımı yer almaktadır. Şekilden de görüleceği üzere çalışmalara katkı sunan toplam 257 yazardan 110’unun (\%43) kadın, 147’sinin (\%57) erkek yazarlardan oluştuğu belirlenmiştir.

Tablo 1. Yayınların Yıllara ve Yayımlandığı Dergilere Göre Dağılımı

\begin{tabular}{|c|c|c|c|c|c|c|c|c|c|c|c|c|}
\hline & \multicolumn{2}{|c|}{ MUFAD } & \multicolumn{2}{|c|}{ MODAV } & \multicolumn{2}{|c|}{ MDB } & \multicolumn{2}{|c|}{ MUVU } & \multicolumn{2}{|c|}{ MÇ } & \multicolumn{2}{c|}{ Toplam } \\
\hline YIL & $\mathbf{n}$ & $\mathbf{\%}$ & $\mathbf{n}$ & $\mathbf{\%}$ & $\mathbf{n}$ & $\mathbf{\%}$ & $\mathbf{n}$ & $\mathbf{\%}$ & $\mathbf{n}$ & $\mathbf{\%}$ & $\mathbf{n}$ & $\mathbf{\%}$ \\
\hline 2016 & 1 & 4 & 5 & 10 & 8 & 21 & 1 & 11 & 4 & 18 & $\mathbf{1 9}$ & $\mathbf{1 3}$ \\
\hline 2017 & 5 & 20 & 6 & 12,5 & 2 & 5 & 1 & 11 & 3 & 14 & $\mathbf{1 7}$ & $\mathbf{1 2}$ \\
\hline 2018 & 4 & 16 & 24 & 50 & 8 & 21 & 1 & 11 & 4 & 18 & $\mathbf{4 1}$ & $\mathbf{2 9}$ \\
\hline 2019 & 9 & 36 & 6 & 12,5 & 12 & 30 & 2 & 22 & 4 & 18 & $\mathbf{3 3}$ & $\mathbf{2 3}$ \\
\hline 2020 & 6 & 24 & 7 & 15 & 9 & 23 & 4 & 45 & 7 & 32 & $\mathbf{3 3}$ & $\mathbf{2 3}$ \\
\hline Toplam & $\mathbf{2 5}$ & $\mathbf{1 0 0}$ & $\mathbf{4 8}$ & $\mathbf{1 0 0}$ & $\mathbf{3 9}$ & $\mathbf{1 0 0}$ & $\mathbf{9}$ & $\mathbf{1 0 0}$ & $\mathbf{2 2}$ & $\mathbf{1 0 0}$ & $\mathbf{1 4 3}$ & $\mathbf{1 0 0}$ \\
\hline
\end{tabular}

Tablo 1'de yayınların yıllara ve yayımlandığı dergilere göre dağılımı ve frekansları bulunmaktadır. Tablodan da görüleceği üzere, denetim konusunda en fazla yayının 48 adet ile (\%34) MODAV'da yayımlandığı, daha sonra sirasıyla, 39 adet (\%27) MDB'de, 25 adet (\%17) MUFAD'da, 22 adet (\%15) MÇ’de ve 9 adet (\%6) MUVU'da yayımlandığ1 belirlenmiştir. Yıl bazında yayımlanan makale sayısının sırasıyla; 2016 yılında 19 adet (\%13), 2017 yllında 17 adet (\%12), 2018 yılında 41 adet (\%29), 2019 ve 2020 yillarında ise 33'er (\%23) adet olduğu tespit edilmiştir. 
Tablo 2. Yayınlarda Kullanılan Araştırma Yönteminin Dergilere Göre Dağılımı

\begin{tabular}{|c|c|c|c|c|c|c|c|c|}
\hline & \multicolumn{2}{|c|}{ Teorik } & \multicolumn{2}{c|}{$\begin{array}{c}\text { Nicel } \\
\text { Araştırma }\end{array}$} & \multicolumn{2}{c|}{$\begin{array}{c}\text { Nitel } \\
\text { Araștırma }\end{array}$} & \multicolumn{2}{c|}{ Toplam } \\
\hline DERGi & $\mathbf{n}$ & $\mathbf{\%}$ & $\mathbf{n}$ & $\mathbf{\%}$ & $\mathbf{n}$ & $\mathbf{\%}$ & $\mathbf{n}$ & $\mathbf{\%}$ \\
\hline MUFAD & 7 & 5 & 15 & 10 & 3 & 2 & $\mathbf{2 5}$ & $\mathbf{1 7}$ \\
\hline MODAV & 14 & 10 & 22 & 15 & 12 & 8 & $\mathbf{4 8}$ & $\mathbf{3 4}$ \\
\hline MDB & 14 & 10 & 11 & 8 & 14 & 10 & 39 & $\mathbf{2 7}$ \\
\hline MUVU & 1 & 1 & 5 & 3 & 3 & 2 & $\mathbf{9}$ & $\mathbf{6}$ \\
\hline MÇ & 9 & 6 & 6 & 4 & 7 & 5 & $\mathbf{2 2}$ & $\mathbf{1 5}$ \\
\hline Toplam & $\mathbf{4 5}$ & $\mathbf{3 1}$ & $\mathbf{5 9}$ & $\mathbf{4 1}$ & $\mathbf{3 9}$ & $\mathbf{2 7}$ & $\mathbf{1 4 3}$ & $\mathbf{1 0 0}$ \\
\hline
\end{tabular}

Tablo 2'de yayınlarda kullanılan araştırma yönteminin dergilere göre dağılımı yer almaktadır. Araştırma yöntemi açısından bakıldığında 45 çalışmanın (\%31) teorik olarak, 59 çalışmanın (\%41) nicel araştırma ve 39 çalışmanın (\%27) nitel araştırma yöntemleri kullanılarak yapıldığı belirlenmiştir. Dergi bazında bakıldığında MUFAD'da 15 çalışma (\%60), MODAV'da 22 çalışma (\%48), MUVU'da 5 çalışma (\%56) ile en çok nicel araştırma yöntemlerinin kullanılmış olduğu, MDB'de 14 çalışma (\%36) ve MÇ'de 9 çalışma (\%41) ile en çok teorik/derleme şeklinde çalışmaların olduğu belirlenmiştir. Sonuçlar değerlendirildiğinde nicel ve nitel yöntem kullanılarak yapılan çalışmaların en çok MUFAD'da yayımlandığı $(18 / 25=\% 72)$ onu MODAV'ın izlediği $(34 / 48=\% 71)$, en fazla teorik çalışmanın yayımlandığı derginin ise $(9 / 22=\% 41)$ MÇ dergisi olduğu tespit edilmiştir.

Tablo 3. Yayınların Yazar Sayısına Göre Dağılımı

\begin{tabular}{|c|c|c|c|c|c|c|c|c|c|c|c|c|}
\hline & \multicolumn{2}{|c|}{ MUFAD } & \multicolumn{2}{|c|}{ MODAV } & \multicolumn{2}{|c|}{ MDB } & \multicolumn{2}{|c|}{ MUVU } & \multicolumn{2}{|c|}{ MÇ } & \multicolumn{2}{c|}{ Toplam } \\
\hline YAZAR SAYISI & $\mathbf{n}$ & $\mathbf{\%}$ & $\mathbf{n}$ & $\mathbf{\%}$ & $\mathbf{n}$ & $\mathbf{\%}$ & $\mathbf{n}$ & $\mathbf{\%}$ & $\mathbf{n}$ & $\mathbf{\%}$ & $\mathbf{n}$ & $\mathbf{\%}$ \\
\hline Tek Yazarlı & 10 & 40 & 21 & 44 & 9 & 23 & 2 & 22 & 13 & 59 & $\mathbf{5 5}$ & $\mathbf{3 8}$ \\
\hline İki Yazarlı & 11 & 44 & 21 & 44 & 23 & 59 & 6 & 67 & 7 & 32 & $\mathbf{6 8}$ & $\mathbf{4 8}$ \\
\hline Çok Yazarlı & 4 & 16 & 6 & 12 & 7 & 18 & 1 & 11 & 2 & 9 & $\mathbf{2 0}$ & $\mathbf{1 4}$ \\
\hline Toplam & $\mathbf{2 5}$ & $\mathbf{1 0 0}$ & $\mathbf{4 8}$ & $\mathbf{1 0 0}$ & $\mathbf{3 9}$ & $\mathbf{1 0 0}$ & $\mathbf{9}$ & $\mathbf{1 0 0}$ & $\mathbf{2 2}$ & $\mathbf{1 0 0}$ & $\mathbf{1 4 3}$ & $\mathbf{1 0 0}$ \\
\hline
\end{tabular}

Tablo 3’te yayınların yazar sayısına göre dağılımı yer almaktadır. Yazar sayılarına bakıldığında; 55 çalışmanın (\%38) tek yazarlı, 68 çalışmanın (\%48) iki yazarlı, 16 çalışmanın ise üç ve daha fazla yazarlı (\%14) olarak yayımlandığı belirlenmiş̦tir. Dergi bazında bakıldığında ise MUFAD'da 11 (\%44), MDB'de 23 (\%59) ve MUVU'da 6 (\%67) çalışma olmak üzere en çok iki yazarlı eserler yayımlanmıştır. MÇ’de 13 (\%59) çalışma ile en çok tek yazarlı eserler yayımlanmıştır. MODAV'da 21'er (\%44) çalışma tek yazarlı ve iki yazarlı eser olarak yayımlanmıştır. Sonuçlar incelendiğinde yayınlanan çalışmaların yarısına yakınının iki yazarlı çalışmalardan oluştuğu dikkat çekmektedir. 
Tablo 4. Yararlanılan Kaynak Sayılarının Dergilere Göre Dağılımı

\begin{tabular}{|c|c|c|c|c|c|c|c|c|c|c|c|c|}
\hline & \multicolumn{2}{|c|}{ MUFAD } & \multicolumn{2}{|c|}{ MODAV } & \multicolumn{2}{|c|}{ MDB } & \multicolumn{2}{c|}{ MUVU } & \multicolumn{2}{|c|}{ MÇ } & \multicolumn{2}{c|}{ Toplam } \\
\hline KAYNAKLAR & $\mathbf{n}$ & $\mathbf{\%}$ & $\mathbf{n}$ & $\mathbf{\%}$ & $\mathbf{n}$ & $\mathbf{\%}$ & $\mathbf{n}$ & $\mathbf{\%}$ & $\mathbf{n}$ & $\mathbf{\%}$ & $\mathbf{n}$ & $\%$ \\
\hline Yabancı Kaynak & 331 & 42 & 1.064 & 61 & 407 & 40 & 203 & 63 & 404 & 56 & $\mathbf{2 . 4 0 9}$ & $\mathbf{5 3}$ \\
\hline Yerli Kaynak & 451 & 58 & 681 & 39 & 600 & 60 & 120 & 37 & 321 & 44 & $\mathbf{2 . 1 7 3}$ & $\mathbf{4 7}$ \\
\hline Toplam & $\mathbf{7 8 2}$ & $\mathbf{1 0 0}$ & $\mathbf{1 . 7 4 5}$ & $\mathbf{1 0 0}$ & $\mathbf{1 . 0 0 7}$ & $\mathbf{1 0 0}$ & $\mathbf{3 2 3}$ & $\mathbf{1 0 0}$ & $\mathbf{7 2 5}$ & $\mathbf{1 0 0}$ & $\mathbf{4 . 5 8 2}$ & $\mathbf{1 0 0}$ \\
\hline
\end{tabular}

Tablo 4'te yararlanılan kaynak sayılarının dergilere göre dağılımı yer almaktadır. Yayınlarda 2.173 (\%47) yerli 2.409 (\%53) yabancı kaynak olmak üzere toplam 4.582 kaynaktan faydalanılmıştır. Dergi bazında yerli ve yabancı kaynak kullanımı, MUFAD \%58 yerli, \%42 yabanc1, MODAV \%39 yerli, \%61 yabanc1, MDB \%60 yerli, \%40 yabanc1, MUVU \%37 yerli, \%63 yabancı ve MÇ \%44 yerli, \%56 yabancı kaynak olduğu görülmektedir.

Tablo 5. Denetim Alt Konularının Yayımlandığı Dergilere Göre Dağılımı

\begin{tabular}{|l|c|c|c|c|c|c|c|c|c|c|c|c|}
\hline & \multicolumn{2}{|c|}{ MUFAD } & \multicolumn{2}{|c|}{ MODAV } & \multicolumn{2}{|c|}{ MDB } & \multicolumn{2}{|c|}{ MUVU } & \multicolumn{2}{|c|}{ MÇ } & \multicolumn{2}{|c|}{ Toplam } \\
\hline Denetim Alt Konusu & $\mathbf{n}$ & $\mathbf{\%}$ & $\mathbf{n}$ & $\mathbf{\%}$ & $\mathbf{n}$ & $\mathbf{\%}$ & $\mathbf{n}$ & $\mathbf{\%}$ & $\mathbf{n}$ & $\mathbf{\%}$ & $\mathbf{n}$ & $\mathbf{\%}$ \\
\hline İç Denetim & 1 & 4 & 7 & 15 & 9 & 23 & 2 & 22 & 4 & 18 & $\mathbf{2 3}$ & $\mathbf{1 6}$ \\
\hline Denetimin Geleceği & 2 & 8 & 8 & 17 & 1 & 3 & 1 & 11 & 3 & 14 & $\mathbf{1 5}$ & $\mathbf{1 0}$ \\
\hline Denetim Kalitesi & 6 & 24 & 1 & 2 & 3 & 8 & 1 & 11 & 1 & 5 & $\mathbf{1 2}$ & $\mathbf{8}$ \\
\hline Denetçi Görüşüi & 1 & 4 & 4 & 8 & 4 & 10 & 0 & 0 & 3 & 14 & $\mathbf{1 2}$ & $\mathbf{8}$ \\
\hline Kilit Denetim & 3 & 12 & 3 & 6 & 3 & 8 & 1 & 11 & 2 & 9 & $\mathbf{1 2}$ & $\mathbf{8}$ \\
\hline Denetçi Karakteristiği & 0 & 0 & 7 & 15 & 1 & 3 & 0 & 0 & 0 & 0 & $\mathbf{8}$ & $\mathbf{6}$ \\
\hline Denetim Raporları & 1 & 4 & 0 & 0 & 4 & 10 & 0 & 0 & 3 & 14 & $\mathbf{8}$ & $\mathbf{6}$ \\
\hline Güvence Denetimi & 1 & 4 & 3 & 6 & 4 & 10 & 0 & 0 & 0 & 0 & $\mathbf{8}$ & $\mathbf{6}$ \\
\hline Etik & 1 & 4 & 5 & 10 & 0 & 0 & 1 & 11 & 0 & 0 & $\mathbf{7}$ & $\mathbf{5}$ \\
\hline Risk Odaklı Denetim & 1 & 4 & 2 & 4 & 2 & 5 & 0 & 0 & 1 & 5 & $\mathbf{6}$ & $\mathbf{4}$ \\
\hline Benford Yasası & 1 & 4 & 2 & 4 & 0 & 0 & 1 & 11 & 0 & 0 & $\mathbf{4}$ & $\mathbf{3}$ \\
\hline Hile Denetimi & 3 & 12 & 0 & 0 & 1 & 3 & 0 & 0 & 0 & 0 & $\mathbf{4}$ & $\mathbf{3}$ \\
\hline Bağımsız denetim (Genel) & 4 & 16 & 6 & 13 & 7 & 18 & 2 & 22 & 5 & 23 & $\mathbf{2 4}$ & $\mathbf{1 7}$ \\
\hline Toplam & $\mathbf{2 5}$ & $\mathbf{1 0 0}$ & $\mathbf{4 8}$ & $\mathbf{1 0 0}$ & $\mathbf{3 9}$ & $\mathbf{1 0 0}$ & $\mathbf{9}$ & $\mathbf{1 0 0}$ & $\mathbf{2 2}$ & $\mathbf{1 0 0}$ & $\mathbf{1 4 3}$ & $\mathbf{1 0 0}$ \\
\hline
\end{tabular}


Tablo 5'te denetim alt konularının yayımlandığı dergilere göre dağılımı yer almaktadır. Yapılan çalışmalar denetim alt konuları bazında incelendiğinde en az $4 \mathrm{kez}$ çalışılmış 12 farklı konu tespit edilmiştir. Bir kez veya iki kez çalışılan konular genel denetim konuları başlığı altında toplanmıştır. Üç kez çalışılan konuya rastlanmamıştır. En çok çalışılan ilk beş alanın 23 adet ile (\%16) iç denetim, 15 adet ile (\%10) denetimin geleceğine ilişkin konular ve 12 'şer adet ile (\%8) kilit denetim, denetim kalitesi ve denetçi görüşleri konuları üzerine olduğu tespit edilmiştir. Sonuçlar, bilimsel çalışmalarda iç denetim çalışmalarına verilen öneminin en az bağımsız denetim çalışmalarına verilen kadar önemli olduğunu göstermektedir.

Tanımlayıcı istatistiksel analizler dışında yayımlanan eserlerin atıf sayılarının değerlendirilmesine yönelik incelemeler sonucunda aşağıdaki bulgular tespit edilmiştir.

Tablo 6. Atıfların Yayımlandığı Dergilere Göre Dağılımı ${ }^{1}$

\begin{tabular}{|l|c|c|c|c|c|}
\hline \multirow{2}{*}{ DERGi } & \multicolumn{2}{|c|}{ Yayın Sayısı } & \multicolumn{2}{c|}{ Atıf Sayısı } & $\begin{array}{c}\text { Yayın Başına } \\
\text { Atıf Sayısı }\end{array}$ \\
\cline { 2 - 6 } & $\mathbf{n}$ & $\mathbf{\%}$ & $\mathbf{n}$ & $\mathbf{\%}$ & $\overline{\mathbf{x}}$ \\
\hline MUFAD & 25 & 17 & 107 & 33 & 4,3 \\
\hline MÇ & 22 & 15 & 59 & 18 & 2,7 \\
\hline MODAV & 48 & 34 & 92 & 28 & 1,9 \\
\hline MDB & 39 & 27 & 63 & 19 & 1,6 \\
\hline MUVU & 9 & 6 & 5 & 2 & 0,6 \\
\hline Toplam & $\mathbf{1 4 3}$ & $\mathbf{1 0 0}$ & $\mathbf{3 2 6}$ & $\mathbf{1 0 0}$ & $\mathbf{2 , 3}$ \\
\hline
\end{tabular}

Tablo 6'da atıfların yayımlandığı dergilere göre dağılımı yer almaktadır. Dergiler bazında en çok atıf alan yayınlar incelendiğinde, 107 alıntının (\%33) MUFAD, 92 alıntının (\%28) MODAV, 63 alıntının (\%19) MDB, 59 alıntının (\%18) MÇ ve 5 alıntının (\%2) MUVU'da yayımlanan çalışmalara yapıldığı tespit edilmiştir. Dergi bazında yayımlanan eser başına atıf sayısına bakıldığında ise MUFAD'da yayımlanan çalışmalar yayın başına 4,3, MÇ'de 2,7, MODAV'da 1,9, MDB'de 1,6 ve MUVU'da 0,6 atıf almıştır. Sonuçlara göre atıf alma bakımından en verimli yayınların MUFAD'da yayımlandığı görülmektedir.

\footnotetext{
${ }^{1}$ Atıf sayılarının belirlenmesinde “Google Akademik” internet arama motorundan, 10.03.2021 tarihi itibariyle elde edilen veriler esas alınmış ve yazarların kendisine yaptığı atıflar da tabloya dahil edilmiştir.
} 
Tablo 7. Atıf Sayılarının Denetim Alt Konularına Göre Dağılımı

\begin{tabular}{|l|c|c|c|c|c|}
\hline & \multicolumn{2}{|c|}{ Yayın Sayısı } & \multicolumn{2}{c|}{ Atıf Sayısı } & $\begin{array}{c}\text { Ortalama } \\
\text { Atıf Sayısı }\end{array}$ \\
\hline Denetim Alt Konusu & $\mathbf{n}$ & $\mathbf{0}$ & $\mathbf{n}$ & $\mathbf{\%}$ & $\overline{\mathbf{x}}$ \\
\hline Kilit Denetim & 12 & 8 & 71 & 22 & 5,9 \\
\hline Denetimin Geleceği & 15 & 10 & 67 & 21 & 4,5 \\
\hline Hile Denetimi & 4 & 3 & 13 & 4 & 3,3 \\
\hline Denetim Raporları & 8 & 6 & 24 & 7 & 3,0 \\
\hline Denetçi Görüşü & 12 & 8 & 32 & 10 & 2,7 \\
\hline Denetçi Karakteristiği & 8 & 6 & 21 & 6 & 2,6 \\
\hline Benford Yasası & 4 & 3 & 9 & 3 & 2,3 \\
\hline İç Denetim & 23 & 16 & 35 & 11 & 1,5 \\
\hline Risk Odaklı Denetim & 6 & 4 & 7 & 2 & 1,2 \\
\hline Etik & 7 & 5 & 7 & 2 & 1,0 \\
\hline Bağımsız Denetim (Genel) & 24 & 17 & 25 & 8 & 1,0 \\
\hline Denetim Kalitesi & 12 & 8 & 10 & 3 & 0,8 \\
\hline Güvence Denetimi & 8 & 6 & 5 & 2 & 0,6 \\
\hline Toplam & $\mathbf{1 4 3}$ & $\mathbf{1 0 0}$ & $\mathbf{3 2 6}$ & $\mathbf{1 0 0}$ & $\mathbf{2 , 3}$ \\
\hline
\end{tabular}

Tablo 7'de atıf sayılarının denetim alt konularına göre dağılımı yer almaktadır. Denetim alt konusu bakımından en çok atıf alan ilk beş çalışmanın, 71 atıf ile (\%22) kilit denetim, 67 atıf ile (\%21) denetimin geleceği, 35 atıf ile (\%11) iç denetim, 32 atıf ile (\%10) denetçi görüşü ve 24 atıf ile (\%7) denetim raporu konulu çalışmalar olduğu belirlenmiştir. Ortalama atıf sayısı en yüksek olan ilk beş çalışmanın ise sırasıyla 5,9 ortalama atıf sayısı ile kilit denetim, 4,5 ortalama atıf sayısı ile denetimin geleceği, 3,3 ortalama atıf sayısı ile hile denetimi, 3,0 ortalama atıf sayıs ile denetim raporları ve 2,7 ortalama atıf sayısı ile denetim görüşü konularına ait çalışmalar olduğu tespit edilmiştir. Sonuçlar değerlendirildiğinde, denetim alanında oldukça yeni sayılabilecek konulardan olan kilit denetim konusunun en çok ortalama atıf alma sayısına sahip olmasını araştırmanın son beş yıllık dönem için yapılmasına bağlamak mümkün olabilir. 
Tablo 8. Atıfların Yayınlarda Kullanılan Araştırma Yöntemine Göre Dağılımı

\begin{tabular}{|l|c|c|c|c|c|}
\hline \multirow{2}{*}{ YAYIN TÜRÜ } & \multicolumn{2}{|c|}{ Yayın Sayısı } & \multicolumn{2}{c|}{ Atıf Sayısı } & $\begin{array}{c}\text { Yayın Başına } \\
\text { Atıf Sayısı }\end{array}$ \\
\cline { 2 - 6 } & $\mathbf{n}$ & $\mathbf{\%}$ & $\mathbf{n}$ & $\mathbf{\%}$ & $\overline{\mathbf{x}}$ \\
\hline Teorik & 45 & 31 & 177 & 54 & 3,9 \\
\hline Nicel Araştırma & 59 & 41 & 90 & 28 & 1,5 \\
\hline Nitel Araştırma & 39 & 27 & 59 & 18 & 1,5 \\
\hline Toplam & $\mathbf{1 4 3}$ & $\mathbf{1 0 0}$ & $\mathbf{3 2 6}$ & $\mathbf{1 0 0}$ & $\mathbf{2 , 3}$ \\
\hline
\end{tabular}

Tablo 8'de atıfların yayınlarda kullanılan araştırma yöntemine göre dağılımı yer almaktadır. Araştırma yöntemine göre, teorik çalışmalar 177 (\%54), nicel yöntemli çalışmalar 90 (\%28), nitel yöntemli çalışmalar ise 59 (\%18) atıf almış ve yayın başına atıf sayısına bakıldığında teorik çalışmalar eser başına 3,9 nicel çalışmalar ve nitel çalışmalar ise 1,5 atıf almıştır. Sonuçlar incelendiğinde, teorik çalışmalara yayın başına yapılan atıf sayısının nicel ve nitel araştırma yöntemleriyle yapılan çalışmaların yayın başına yapılan atıf sayısı toplamından daha fazla olduğu görülmektedir. Bu durumun, bilimsel çalışmalarda teorik kısımların yazılmasında ampirik araştırmalardan ziyade teorik çalışmalardan faydalanılmasından kaynaklı olabileceği düşünülebilir.

Tablo 9. Atıfların Yayınlardaki Yazar Sayısına Göre Dağılımı

\begin{tabular}{|c|c|c|c|c|c|}
\hline \multirow{2}{*}{ YAZAR SAYISI } & \multicolumn{2}{|c|}{ Yayın Sayısı } & \multicolumn{2}{c|}{ Atıf Sayısı } & $\begin{array}{c}\text { Yayın Başına } \\
\text { Atıf Sayısı }\end{array}$ \\
\cline { 2 - 6 } & $\mathbf{n}$ & $\mathbf{\%}$ & $\mathbf{n}$ & $\mathbf{\%}$ & $\overline{\mathbf{x}}$ \\
\hline Tek Yazarlı & 56 & 39 & 162 & 50 & 2,9 \\
\hline İki Yazarlı & 67 & 47 & 132 & 40 & 2,0 \\
\hline Çok Yazarlı & 20 & 14 & 32 & 10 & 1,6 \\
\hline Toplam & $\mathbf{1 4 3}$ & $\mathbf{1 0 0}$ & $\mathbf{3 2 6}$ & $\mathbf{1 0 0}$ & $\mathbf{2 , 3}$ \\
\hline
\end{tabular}

Tablo 9'da atıfların yayınlardaki yazar sayısına göre dağılımı yer almaktadır. Yazar sayısına göre atıf sayıları ele alındığında, tek yazarlı çalışmalara 162 atıf (\%50), iki yazarlı çalışmalara $132(\% 40)$ ve çok yazarlı çalışmalara 32 atıf $(\% 10)$ yapıldığ Yayın başına atıf sayısına bakıldığında tek yazarlı çalışmaların ortalama 2,9, iki yazarlı çalışmaların ortalama 2 ve çok yazarlı çalışmaların ortalama 1,6 atıf aldığı belirlenmiştir. Bu sonuçlara göre en çok atıf alan çalışmaların tek yazarlı yayınlar olduğu ortaya çıkmıştır. Burada dikkat çeken bir husus, kapsam dahilindeki çalışmaların yarısına yakınının iki yazarlı olmasına karşın tek yazarlı çalışmaların daha fazla sayıda atıf almasıdır. 
Tablo 10. Atıf Almayan Yayınların Dergilere Göre Dağılımı

\begin{tabular}{|l|c|c|}
\hline \multirow{2}{*}{ Dergi Adı } & \multicolumn{2}{|c|}{ Atıf Almayan Yayınlar } \\
\cline { 2 - 3 } & $\mathbf{n}$ & $\mathbf{\%}$ \\
\hline MODAV & 26 & 34 \\
\hline MDB & 22 & 29 \\
\hline MÇ & 11 & 14 \\
\hline MUFAD & 11 & 14 \\
\hline MUVU & 7 & 9 \\
\hline Toplam & $\mathbf{7 7}$ & $\mathbf{1 0 0}$ \\
\hline
\end{tabular}

Tablo10 incelendiğinde, analize tabi tutulan 77 yayının henüz atıf almadığı görülmektedir. Bu yayınlardan 26'sı (\%34) MODAV, 22'si (\%29) MDB, 11'i (\%14) MUFAD, 11'i (\%14) MÇ ve 7'si (\%9) MUVU'da yayımlandığı belirlenmiştir. Dergilerin kendi içinde atıf almayan yayınlar karşılaştırıldığında, MUFAD'da yayımlanan makalelerin \%44'ü (11/25=0,44), MÇ’de \%50'si (11/22=0,50), MODAV'da \%54'ü (26/48=0,54), MDB'de \%56'sı $(22 / 39=0,56)$ ve MUVU'da \%78'inin (7/9=0,78) henüz atıf almadığ tespit edilmiştir. Ortaya çıkan sonuç MUFAD’da yayımlanan dergilerin atıf verimliliğinin daha yüksek olduğunu göstermektedir.

Tablo 11. Atıfların Faydalanılan Kaynak Türüne Göre Dağılımı

\begin{tabular}{|l|c|c|c|c|c|c|}
\hline \multirow{2}{*}{ KAYNAK TÜRÜ } & \multicolumn{2}{|c|}{$\begin{array}{c}\text { Henüz Atıf } \\
\text { Almamıs Yayınlarda }\end{array}$} & \multicolumn{2}{|c|}{ Atıf Almıs Yayınlarda } & \multicolumn{2}{c|}{ Toplam } \\
\cline { 2 - 7 } & $\mathbf{n}$ & $\%$ & $\mathbf{n}$ & $\%$ & $\mathbf{n}$ & $\%$ \\
\hline Yabancı Kaynak & 1.331 & 52 & 1.078 & 53 & $\mathbf{2 . 4 0 9}$ & $\mathbf{5 3}$ \\
\hline Yerli Kaynak & 1.209 & 48 & 964 & 47 & $\mathbf{2 . 1 7 3}$ & $\mathbf{4 7}$ \\
\hline Toplam & $\mathbf{2 . 5 4 0}$ & $\mathbf{1 0 0}$ & $\mathbf{2 . 0 4 2}$ & $\mathbf{1 0 0}$ & $\mathbf{4 . 5 8 2}$ & $\mathbf{1 0 0}$ \\
\hline
\end{tabular}

Tablo 11 incelendiğinde, yayınlarda kullanılan yerli ve yabancı kaynak sayılarına göre atıf sayılarına bakıldığında, henüz atıf almayan yayınlar ile atıf alan yayınlar arasında anlamlı bir farlılık tespit edilmemiştir. Henüz atıf almayan yayınların \%48'i yerli, \%52'si yabancı, atıf alan yayınların ise \%47'si yerli, \%53'ü yabancı kaynaklardan faydalanılarak hazırlanmıştır. $\mathrm{Bu}$ durum yayınlarda kullanılan kaynak türünün atıf sayısında etkili olmadığını göstermektedir. 


\section{SONUÇ}

Muhasebe alanında yayımlanan seçilmiş beş dergi kapsamında 2016-2020 yılları arasında denetim konuları üzerine yapılan 143 yayının bibliyometrik analizi sonucunda, en fazla yayının MODAV'da yayımlandığı, en fazla çalışmanın 41 adet ile 2018 yılında yayımlandığı, çalışmalarda 59 adet ile en fazla nicel araştırma yöntemlerinin kullanıldığı, çalışmalara yazar cinsiyeti olarak en fazla katkının 147 katkı sayısı ile erkek yazarlar tarafından yapıldığ 1 , yazar sayısı bakımından en fazla yayının 68 adet ile iki yazarlı çalışmalarda olduğu, en fazla çalışılan denetim alt konusunun 23 adet ile iç denetim konusu olduğu ve çalışmalarda yabancı kaynaklara daha fazla başvurulduğu tespit edilmiştir. Yayın başına en fazla atıf alan çalışmalar incelendiğinde; dergi bazında 4,3 atıf ortalaması ile MUFAD, yayın türü olarak 3,9 atıf ortalaması ile teorik çalışmalar, yazar sayısı olarak 2,9 atıf ortalaması ile tek yazarlı çalışmalar, çalışma alt konusu olarak ise 5,9 atıf ortalaması ile kilit denetim konusu olduğu tespit edilmiştir.

$\mathrm{Bu}$ çalışmada, denetim alanında son yıllarda yayımlanmış bilimsel çalışmaların durumu ve güncel konular belirlenmiş ve ayrıca bu çalışmaların verimliliği ortaya konmuştur. Muhasebe bilimi çok geniş bir alana sahip olduğundan denetim konusu gibi; finansal raporlama, muhasebe ve denetim standartları, vergi uygulamaları, maliyet ve yönetim muhasebesi gibi alt konular bazında yapılan çalışmaların da bibliyometrik olarak incelenmesinin bu alt alanlarda bundan sonraki yapılacak olan çalışmalara 1şık tutacağı ve araştırmalara yön verebileceği düşünülmektedir.

\section{KAYNAKLAR}

Akgün, Melek - Karataş, Bekir (2017), "Muhasebe ve Denetime Bakış Dergisinde Yayımlanan Makalelerin Bibliyometrik Analizi (2000-2016)”, Muhasebe ve Denetime Bakış Dergisi, 17(52), ss. 19-34.

Al, Umut (2008), Türkiye'nin Bilimsel Yayın Politikası: Atıf Dizinlerine Dayalı Bibliyometrik Bir Yaklaşım, (Yayımlanmamış Doktora Tezi), Hacettepe Üniversitesi Sosyal Bilimler Enstitüsü, Ankara.

Apak, Sudi - Erol, Mikail - Öztürk, Seçil (2016), "Muhasebe ve Finans Tarihi Araştırmaları Dergisinde Yayınlanan Makalelerin Bibliyometrik Analizi", Muhasebe ve Finans Tarihi Araştırmaları Dergisi, (11), ss. 111-124.

Başpınar, Ahmet (2005), Türkiye'de ve Dünyada Denetim Standartlarının Oluşumuna Genel Bir Bakış. Maliye Dergisi, 148, ss. 35-62.

Bozkurt, Nejat (2012), "Muhasebe Denetimi”, 6. Bask1, Alfa Yayınları, İstanbul.

Ceylan, Erdoğan (2019), Muhasebe ve Denetimde Güncel Konular, Ed. Erol Fidan, Meral, Efe Akademi Yayınevi, İstanbul.

Erol Fidan, Meral (2019), Muhasebe ve Denetimde Güncel Konular, Ed. Erol Fidan, Meral, Efe Akademi Yayınevi, İstanbul. 
Güredin, Ersin (2010), “Denetim ve Güvence Hizmetleri”, 13. Bask1, Türkmen Kitabevi, İstanbul.

Hotamışl1, Mustafa - Erem, Işıl (2014), "Muhasebe Ve Finansman Dergisi'nde Yayınlanan Makalelerin Bibliyometrik Analizi", Muhasebe ve finansman dergisi, 63, ss. 1-20.

Kaya, H. Pınar (2019), “Türkiye'de Denetim Alanında Yazılmış Olan Doktora Tezlerinin Değerlendirilmesi”, Karabük Üniversitesi Sosyal Bilimler Enstitüsü Dergisi, 9(2), ss. 556-576.

Kozak, Nazmi (2003), “Türkiye'de Yayınlanan Akademik Dergilerin Niteliklerindeki Zaman İçerisindeki Değişim Nedenleri: Sağlık, Sosyal ve Teknik Bilim Alanlarında Yayınlanan Dergiler Üzerine Bir İnceleme”, Bilgi Dünyası Dergisi, 4(2), ss. 146-174.

Kuruçay, Çiğdem - Serçemeli, Murat (2018), "Hile Alanında Bilimsel Dergilerde Yer Alan Ulusal Makaleler: (2008-2017 Literatür Taramas1)", Muhasebe ve Denetime Bakiş Dergisi, 18(55), ss. 161-174.

Mcburney, Melissa K. - Novak, Pamela L. (2002), "What İs Bibliometrics And Why Should You Care? Professional Communication Conference, IPCC. Proceedings, pp. 108-114. https://İeexplore.İeee.Org/Stamp/Stamp.Jsp?Tp=\&Arnumber=1049094, （Erişim: 10.03.2020)

Önce, Saime - Başar, Banu (2010), “Türkiye'deki Akademik Araştırma Dergilerinde Muhasebe Alanında Yazılmış Makalelerin Analizi: 2000-2008”, Muhasebe ve Finansman Dergisi, 45, ss. 55-68.

Özbek, Cevdet Yiğit - Badem, Ahmet Cemkut (2018), Muhasebe Ve Vergi Uygulamaları Dergisi Yayımlanmış Makalelerin Bibliyometrik Analizi (2008-2017), Muhasebe ve Vergi Uygulamaları Dergisi, 11(2), ss. 216-247.

Özinönü, Ahmet Kemal (1970), “Growth İn Turkish Positive Basic Sciences, 1933-1966”, Middle East Technical University, Faculty Of Arts And Sciences (No. 17).

Parlak, Neşegül (2020), "Muhasebe Denetimine İlişkin Lisansüstü Tezlerin İncelenmesi”, Mali Çözüm Dergisi, 30(160), ss. 195-210.

Pritchard, Alan (1969), “Statistical Bibliography Or Bibliometrics”, Journal of Documentation, 25, pp. 348-349.

Polat, Coşkun - Sağlam Mukaddes - Sarı, Tuğba (2013), "Atatürk Üniversitesi İktisadi ve İdari Bilimler Dergisi'nin Bibliyometrik Analizi”, Atatürk Üniversitesi İktisadi ve İdari Bilimler Dergisi, 27(2), ss. 273-288.

Sakin, Turgay (2008), “İşletme Fakültesi Dergisi’nde 1972-2007 Yılları Arasında Yayınlanan Muhasebe Finansman Makalelerinin İncelenmesi", İstanbul Üniversitesi İşletme Fakültesi Dergisi, 37(1), ss. 13-21. 
Selimoğlu, Seval Kardeş - Uzay, Şaban (2007), "Türkiye'de Denetim Alanında Yapılan Araştırmalar (1995-2005) ve Seçme Yazılar", İstanbul Serbest Muhasebeci ve Mali Müşavirler Odası Yayını, Yayın No. 82. İstanbul.

Uysal, Özgür Özmen (2009), "Muhasebe ve Bilim Dünyası Dergisi (2004-2006) Üzerinden Muhasebe Araştırmalarının Bibliyometrik Analizi”, XXVIII. Türkiye Muhasebe Eğitimi Sempozyumu, İzmir, ss. 181-198.

Uzay, Şaban - Tanç, Ahmet - Erciyes, Mehmet (2009), “Türkiye'de Muhasebe Denetimi: Geçmişten Geleceğe-1”, Mali Çözüm Dergisi, 95, ss. 125-140. 


\section{EK 1: Yayınların İçerik Analizi}

\begin{tabular}{|c|c|c|c|c|c|c|c|c|c|}
\hline $\begin{array}{l}\text { Sira } \\
\text { No }\end{array}$ & Y1l & $\begin{array}{l}\text { Yayin } \\
\text { Yeri }\end{array}$ & Yazar(lar) & Yayın Başlığı & $\begin{array}{l}\text { Yayın } \\
\text { Türü }\end{array}$ & $\begin{array}{c}\text { Ana } \\
\text { Tema }\end{array}$ & Atıf & $\begin{array}{c}\text { Yerli } \\
\text { Kaynak }\end{array}$ & $\begin{array}{l}\text { Yabanc1 } \\
\text { Kaynak }\end{array}$ \\
\hline 1 & 2016 & MUFAD & $\begin{array}{l}\text { Suphi ASLANOĞLU } \\
\text { Selim CENGİZ } \\
\text { Yusuf DİÇ } \\
\text { M. Ş̈̈rü DİLSİZ }\end{array}$ & $\begin{array}{l}\text { Yaratıcı Muhasebe } \\
\text { Uygulamalarının Bağımsız } \\
\text { Denetim Kalitesi Üzerine Etkisi: } \\
\text { BİST’de Bir Uygulama }\end{array}$ & $\begin{array}{c}\text { Nicel } \\
\text { Araştırma }\end{array}$ & $\begin{array}{l}\text { Bağımsız } \\
\text { Denetim } \\
\text { Kalitesi }\end{array}$ & 6 & 10 & 9 \\
\hline 2 & 2017 & MUFAD & $\begin{array}{c}\text { Serap YANIK } \\
\text { Muharrem } \\
\text { KARATAŞ } \\
\end{array}$ & $\begin{array}{l}\text { Denetim Raporlarının Geleceği: } \\
\text { Yeni Düzenlemeler Ve Ülke } \\
\text { Uygulamaları }\end{array}$ & Derleme & $\begin{array}{c}\text { Kilit } \\
\text { Denetim }\end{array}$ & 24 & 12 & 6 \\
\hline 3 & 2017 & MUFAD & H. Pınar KAYA & $\begin{array}{l}\text { Bağımsız Denetçilerin Açılış } \\
\text { Bakiyeleri Denetimlerine İlişkin } \\
\text { Görüşleri: Ankara İlinde Nitel Bir } \\
\text { Araştırma }\end{array}$ & $\begin{array}{c}\text { Nitel } \\
\text { Araştırma }\end{array}$ & Genel & 0 & 13 & 14 \\
\hline 4 & 2017 & MUFAD & Kıvanç ERTİKIN & $\begin{array}{l}\text { Hile Denetimi: Kırmızı } \\
\text { Bayrakların Tespiti için Kullanılan } \\
\text { Proaktif Yaklaşımlar }\end{array}$ & Derleme & $\begin{array}{l}\text { Hile } \\
\text { Denetimi }\end{array}$ & 13 & 22 & 17 \\
\hline 5 & 2017 & MUFAD & $\begin{array}{c}\text { İkay Ejder } \\
\text { ERTURAN } \\
\text { Emre ERGIN } \\
\end{array}$ & $\begin{array}{l}\text { Muhasebe Denetiminde Nesnelerin } \\
\text { İnterneti: Stok Döngüsü }\end{array}$ & Derleme & $\begin{array}{l}\text { Denetimin } \\
\text { Geleceği }\end{array}$ & 30 & 13 & 19 \\
\hline 6 & 2017 & MUFAD & $\begin{array}{c}\text { Mihriban COŞKUN } \\
\text { ARSLAN } \\
\text { Serkan DEMİRKAN }\end{array}$ & Auditing And Assurance Services & Derleme & $\begin{array}{l}\text { Güvence } \\
\text { Denetimi }\end{array}$ & 0 & 6 & 17 \\
\hline 7 & 2018 & MUFAD & Ahmet ÖZCAN & $\begin{array}{l}\text { Analyzing Determinants of } \\
\text { Auditor Choice: Evidence from } \\
\text { Borsa İstanbul }\end{array}$ & $\begin{array}{c}\text { Nicel } \\
\text { Araştırma }\end{array}$ & Genel & 4 & 0 & 52 \\
\hline 8 & 2018 & MUFAD & $\begin{array}{c}\text { Hasan TÜREDİ } \\
\text { Tolga ALA } \\
\text { Şükrü Mete } \\
\text { TEPEGÖZ } \\
\end{array}$ & $\begin{array}{l}\text { Uluslararası Denetim Standartları } \\
\text { Açısından Kurumsal Yönetim } \\
\text { Sürecinin Değerlendirilmesi }\end{array}$ & Derleme & Genel & 0 & 12 & 5 \\
\hline 9 & 2018 & MUFAD & $\begin{array}{l}\text { Mehmet Akif ÖNCÜ } \\
\text { Rahmi YÜCEL } \\
\text { Onur ÖZEVIN } \\
\end{array}$ & $\begin{array}{l}\text { Benford Analizi İle Muhasebe } \\
\text { Denetimi: Kamu Hastaneleri } \\
\text { Üzerine Bir Uygulama }\end{array}$ & $\begin{array}{c}\text { Nicel } \\
\text { Araştırma }\end{array}$ & $\begin{array}{l}\text { Benford } \\
\text { Yasası }\end{array}$ & 3 & 12 & 11 \\
\hline 10 & 2018 & MUFAD & $\begin{array}{c}\text { Bilge SEKİZSU } \\
\text { Fatih Coşkun ERTAŞ }\end{array}$ & $\begin{array}{l}\text { Şirketlerin Bağımsız Denetim } \\
\text { Raporlarının Analizi: Borsa } \\
\text { İstanbul'da Bir Araştırma }\end{array}$ & $\begin{array}{c}\text { Nicel } \\
\text { Araştırma }\end{array}$ & $\begin{array}{l}\text { Denetçi } \\
\text { Görüşü }\end{array}$ & 5 & 12 & 0 \\
\hline 11 & 2019 & MUFAD & Yasin KARADENİZ & $\begin{array}{l}\text { Türkiye'de Bağımsız Denetim } \\
\text { Sistemindeki Gelişmeler: Denetim } \\
\text { Kuruluşlarında Çalışan Denetçilere } \\
\text { Yönelik Bir Araştırma }\end{array}$ & $\begin{array}{c}\text { Nicel } \\
\text { Araştırma }\end{array}$ & $\begin{array}{l}\text { Denetimin } \\
\text { Geleceği }\end{array}$ & 3 & 19 & 2 \\
\hline 12 & 2019 & MUFAD & İlker CALAYOĞLU & $\begin{array}{l}\text { Elektronik Vergi Denetimindeki } \\
\text { Teknolojik Gelişmeler ve Tam } \\
\text { Denetime Geçiş Adımları }\end{array}$ & Derleme & $\begin{array}{c}\text { Risk } \\
\text { Odaklı } \\
\text { Denetim }\end{array}$ & 4 & 38 & 7 \\
\hline 13 & 2019 & MUFAD & $\begin{array}{l}\text { Mehmet DEMİR } \\
\text { M. Mustafa } \\
\text { KISAKÜREK } \\
\text { Öznur ARSLAN } \\
\end{array}$ & $\begin{array}{l}\text { İç Denetim Sisteminin Hileli } \\
\text { Finansal Raporlamayı Önlemedeki } \\
\text { Rolüne Yönelik Bağımsız } \\
\text { Denetçiler Üzerinde Bir Araştırma }\end{array}$ & $\begin{array}{c}\text { Nicel } \\
\text { Araştırma }\end{array}$ & $\begin{array}{c}\text { İç } \\
\text { Denetim }\end{array}$ & 3 & 32 & 12 \\
\hline 14 & 2019 & MUFAD & $\begin{array}{l}\text { Aysel ÖZTÜRKÇÜ } \\
\text { AKÇAY } \\
\text { Abdulkadir BİLEN }\end{array}$ & $\begin{array}{l}\text { Denetim Kalitesinin Kar Yönetimi } \\
\text { Üzerine Etkisi: Bist-100 Firmaları } \\
\text { Üzerine Bir Uygulama }\end{array}$ & $\begin{array}{c}\text { Nicel } \\
\text { Araştırma }\end{array}$ & $\begin{array}{l}\text { Bağımsız } \\
\text { Denetim } \\
\text { Kalitesi } \\
\end{array}$ & 1 & 4 & 47 \\
\hline 15 & 2019 & MUFAD & $\begin{array}{c}\text { Gülsün } \\
\text { İŞSEVEROĞLU }\end{array}$ & $\begin{array}{l}\text { Bağımsız Denetim Raporunda } \\
\text { Kilit Denetim Konuları: BİST } \\
\text { Sigorta Şirketlerinin 2017-2018 } \\
\text { Y1lları Analizi }\end{array}$ & $\begin{array}{c}\text { Nitel } \\
\text { Araştırma }\end{array}$ & $\begin{array}{c}\text { Kilit } \\
\text { Denetim }\end{array}$ & 2 & 16 & 0 \\
\hline 16 & 2019 & MUFAD & $\begin{array}{c}\text { Fatma } \\
\text { TEKTÜFEKÇİ }\end{array}$ & $\begin{array}{l}\text { An Examination On The } \\
\text { Interaction Between Concordat, } \\
\text { The Concordat Commissariat, And } \\
\text { The Independent Audit Report:An } \\
\text { Example Of The Independent } \\
\text { Reasonable Assurance Report For } \\
\text { A Preliminary Concordat Project }\end{array}$ & Kuramsal & $\begin{array}{c}\text { Denetim } \\
\text { Raporu }\end{array}$ & 0 & 8 & 8 \\
\hline 17 & 2019 & MUFAD & $\begin{array}{l}\text { Seval SELIMOĞLU } \\
\text { Mehtap ALTUNEL }\end{array}$ & $\begin{array}{l}\text { Master/Phd Theses Prepared } \\
\text { About Financial Statement Fraud } \\
\text { And Fraud Audit: Academic } \\
\text { Literature Between } 2008 \text { And } 2018 \\
\text { In Turkey }\end{array}$ & $\begin{array}{c}\text { Nitel } \\
\text { Araştırma }\end{array}$ & $\begin{array}{c}\text { Hile } \\
\text { Denetimi }\end{array}$ & 0 & 12 & 4 \\
\hline
\end{tabular}




\begin{tabular}{|c|c|c|c|c|c|c|c|c|c|}
\hline 18 & 2019 & MUFAD & Murat ATİK & $\begin{array}{l}\text { Davranışsal Denetim: Finansal } \\
\text { Tablo Hilelerin Hüristik Bir } \\
\text { Yaklaşımla İncelenmesi }\end{array}$ & $\begin{array}{c}\text { Nicel } \\
\text { Araştırma }\end{array}$ & $\begin{array}{c}\text { Hile } \\
\text { Denetimi }\end{array}$ & 0 & 10 & 3 \\
\hline 19 & 2019 & MUFAD & $\begin{array}{l}\text { Yasemin ERTAN } \\
\text { Ekinç KIZIK }\end{array}$ & $\begin{array}{l}\text { Kilit Denetim Konuları: BİST } \\
\text { İmalat Sektöründe Faliyette } \\
\text { Bulunan İşletmelerin } 2017 \text { Y1lı } \\
\text { Denetim Raporlarının İncelenmesi }\end{array}$ & $\begin{array}{c}\text { Nitel } \\
\text { Araştırma }\end{array}$ & $\begin{array}{c}\text { Kilit } \\
\text { Denetim }\end{array}$ & 6 & 12 & 2 \\
\hline 20 & 2020 & MUFAD & Merve ACAR & $\begin{array}{l}\text { Finansal Raporlama Kalitesi İle } \\
\text { Denetim Kalitesi Arasındaki } \\
\text { İlişkinin Türk Bankacılık Sektörü } \\
\text { Çerçevesinde İncelenmesi }\end{array}$ & $\begin{array}{c}\text { Nicel } \\
\text { Araştırma }\end{array}$ & $\begin{array}{l}\text { Bağımsız } \\
\text { Denetim } \\
\text { Kalitesi }\end{array}$ & 0 & 129 & 4 \\
\hline 21 & 2020 & MUFAD & Arzu MERİÇ & $\begin{array}{l}\text { Hile Denetiminde Whistleblowing } \\
\text { ve Whistleblowing Niyetini } \\
\text { Etkileyen Faktörler: Kayseri’de } \\
\text { Faaliyet Gösteren Muhasebeciler } \\
\text { İle Amprik Bir Çalışma }\end{array}$ & $\begin{array}{c}\text { Nicel } \\
\text { Araştırma }\end{array}$ & Etik & 0 & 17 & 22 \\
\hline 22 & 2020 & MUFAD & $\begin{array}{c}\text { Şerife ÖNDER } \\
\text { İ.Etem İRKÖRÜCÜ }\end{array}$ & $\begin{array}{l}\text { Bağımsız Denetim Kalitesi İle } \\
\text { Finansal Performans Arasındaki } \\
\text { İlişki: BIST } 100 \text { Endeksinde Yer } \\
\text { Alan Şirketler Üzerine Bir } \\
\text { Araştırma }\end{array}$ & $\begin{array}{c}\text { Nicel } \\
\text { Araştırma }\end{array}$ & $\begin{array}{l}\text { Bağımsız } \\
\text { Denetim } \\
\text { Kalitesi }\end{array}$ & 0 & 8 & 14 \\
\hline 23 & 2020 & MUFAD & $\begin{array}{l}\text { Seden ÖZGER } \\
\text { Osman TUĞAY }\end{array}$ & $\begin{array}{l}\text { Bağımsız Denetimde Zorunlu } \\
\text { Rotasyonun Denetçi Bağımsızlığı } \\
\text { ve Denetim Kalitesine Etkisi ve } \\
\text { Rotasyon ile Denetim Kalitesi } \\
\text { Arasındaki İlişkide Denetçi } \\
\text { Bağımsızlığının Aracılık Rolü: } \\
\text { Bağımsız Denetçilerin } \\
\text { Algılarına Yönelik Bir Araştırma }\end{array}$ & $\begin{array}{c}\text { Nicel } \\
\text { Araştırma }\end{array}$ & $\begin{array}{l}\text { Bağımsız } \\
\text { Denetim } \\
\text { Kalitesi }\end{array}$ & 0 & 18 & 22 \\
\hline 24 & 2020 & MUFAD & $\begin{array}{l}\text { Reyhan SARIÇİÇEK } \\
\text { Mehmet AYTEKİN }\end{array}$ & $\begin{array}{l}\text { Türkiye'deki Bağımsız } \\
\text { Denetçilerin Denetim Kalitesini } \\
\text { Azaltan Davranışlarının Analizi }\end{array}$ & $\begin{array}{c}\text { Nicel } \\
\text { Araştırma }\end{array}$ & $\begin{array}{l}\text { Bağımsız } \\
\text { Denetim } \\
\text { Kalitesi }\end{array}$ & 0 & 11 & 26 \\
\hline 25 & 2020 & MUFAD & $\begin{array}{l}\text { Necdet SAĞLAM } \\
\text { Abdullah ORHAN }\end{array}$ & $\begin{array}{l}\text { Audit Market Concentration in } \\
\text { Turkey: An Empirical Study of the } \\
\text { Relationship between the Audit } \\
\text { Firm Characteristics }\end{array}$ & $\begin{array}{c}\text { Nicel } \\
\text { Araştırma }\end{array}$ & Genel & 3 & 5 & 8 \\
\hline 26 & 2016 & MÖDAV & $\begin{array}{c}\text { Hakan } \\
\text { BAYRAKTAROĞLU }\end{array}$ & $\begin{array}{l}\text { İşletmelerde Muhasebe Hata Ve } \\
\text { Hilelerinin Önlenmesinde Etkin İç } \\
\text { Denetimin Rolü Ve Önemi } \\
\text { Üzerine Bir Alan Araştırması }\end{array}$ & $\begin{array}{c}\text { Nicel } \\
\text { Araştırma }\end{array}$ & $\begin{array}{c}\text { İç } \\
\text { Denetim }\end{array}$ & 7 & 25 & 3 \\
\hline 27 & 2016 & MÖDAV & Koray TUAN & $\begin{array}{l}\text { Kurumsal Yönetim Endeksinde } \\
\text { Yer Alan İşletmelerde Etkin İç } \\
\text { Kontrol ve Bağımsız Denetim } \\
\text { Göstergeleri }\end{array}$ & $\begin{array}{c}\text { Nicel } \\
\text { Araştırma }\end{array}$ & $\begin{array}{l}\text { Denetçi } \\
\text { Karakteris } \\
\text { tiği }\end{array}$ & 6 & 21 & 33 \\
\hline 28 & 2016 & MÖDAV & $\begin{array}{l}\text { Mehmet } \\
\text { ÖZBİRECİKLİ } \\
\text { Joshiaki JINNAI } \\
\text { Nertila CIKA }\end{array}$ & $\begin{array}{l}\text { Can Types Of Wrongdoings And } \\
\text { The Corruption Perception Scores } \\
\text { Be Criteria To Define Audit } \\
\text { Thresholds For Non-Listed } \\
\text { Companıes? The Cases Of Turkey, } \\
\text { Japan And Albania }\end{array}$ & $\begin{array}{c}\text { Nitel } \\
\text { Araştırma }\end{array}$ & Genel & 1 & 12 & 13 \\
\hline 29 & 2016 & MÖDAV & $\begin{array}{l}\text { Yasin ŞEKER } \\
\text { Engin DİNÇ }\end{array}$ & $\begin{array}{l}\text { Bağımsız Denetim Şirketlerinde } \\
\text { Kalite Kontrol Standartlarının } \\
\text { Uygulanma Etkinliğini Ölçmeye } \\
\text { Yönelik Bir Çalışma: Türkiye } \\
\text { Örneği }\end{array}$ & $\begin{array}{c}\text { Nicel } \\
\text { Araştırma }\end{array}$ & Genel & 2 & 18 & 22 \\
\hline 30 & 2016 & MÖDAV & $\begin{array}{l}\text { S. Serap YANIK } \\
\text { Can ÖZTÜRK }\end{array}$ & $\begin{array}{l}\text { Türkiye Denetim ve Güvence } \\
\text { Standartları Kapsamında İleriye } \\
\text { Yönelik Finansal Bilgiye İlişkin } \\
\text { Güvence Raporlarının GDS } 3400 \\
\text { Açısından İncelenmesi }\end{array}$ & $\begin{array}{c}\text { Nitel } \\
\text { Araştırma }\end{array}$ & $\begin{array}{l}\text { Güvence } \\
\text { Denetimi }\end{array}$ & 0 & 8 & 1 \\
\hline 31 & 2017 & MÖDAV & Özgecan ÖZER & $\begin{array}{l}\text { Geleceğin Denetimi - İleriye } \\
\text { Yönelik Finansal Bilgilerin } \\
\text { İncelenmesi }\end{array}$ & Derleme & $\begin{array}{l}\text { Güvence } \\
\text { Denetimi }\end{array}$ & 0 & 1 & 12 \\
\hline 32 & 2017 & MÖDAV & $\begin{array}{l}\text { Neslihan } \\
\text { ÇETİNKAYA }\end{array}$ & $\begin{array}{l}\text { Risk Odaklı Denetimde Denetim } \\
\text { Kanıtının Kalitesinin Önemi ve Bir } \\
\text { Araştırma }\end{array}$ & $\begin{array}{c}\text { Nitel } \\
\text { Araştırma }\end{array}$ & $\begin{array}{l}\text { Denetçi } \\
\text { Görüşü }\end{array}$ & 6 & 12 & 3 \\
\hline
\end{tabular}




\begin{tabular}{|c|c|c|c|c|c|c|c|c|c|}
\hline 33 & 2017 & MÖDAV & Alpaslan YAŞA & $\begin{array}{l}\text { İ̧̧letmenin Sürekliliğinde Ortaya } \\
\text { Çıkan Belirsizliğin Bağımsız } \\
\text { Denetim Raporlarındaki Denetçi } \\
\text { Görüşleri Açısından İncelenmesi: } \\
\text { Bist'de İşlem Gören Sınai } \\
\text { Şirketlerine Yönelik Bir Araştırma }\end{array}$ & $\begin{array}{c}\text { Nicel } \\
\text { Araştırma }\end{array}$ & $\begin{array}{l}\text { Denetçi } \\
\text { Görüşü }\end{array}$ & 6 & 26 & 40 \\
\hline 34 & 2017 & MÖDAV & İklim Elif UMUT & $\begin{array}{l}\text { Yatırım Fonlarının Mali } \\
\text { Tablolarına İliş̧kin Denetçi } \\
\text { Görüşleri İle Denetçi Rotasyonu } \\
\text { Arasındaki İlişki }\end{array}$ & $\begin{array}{c}\text { Nitel } \\
\text { Araştırma }\end{array}$ & $\begin{array}{l}\text { Denetçi } \\
\text { Görüşü }\end{array}$ & 0 & 36 & 2 \\
\hline 35 & 2017 & MÖDAV & Kıvanç ERTİKİN & $\begin{array}{l}\text { Hile Denetimi: Benford Yasası'nın } \\
\text { Bilgisayar Destekli Kullanımına } \\
\text { Yönelik Bir Hizmet İşletmesi } \\
\text { Örneği }\end{array}$ & $\begin{array}{c}\text { Nicel } \\
\text { Araştırma }\end{array}$ & $\begin{array}{l}\text { Benford } \\
\text { Yasası }\end{array}$ & 4 & 9 & 13 \\
\hline 36 & 2017 & MÖDAV & Naz SAYARI & $\begin{array}{l}\text { Contemporary Issues In } \\
\text { Behavıoral Audıtıng: A Revıew Of } \\
\text { Behavıoral Audıt Research }\end{array}$ & $\begin{array}{c}\text { Nitel } \\
\text { Araştırma }\end{array}$ & $\begin{array}{c}\text { Denetçi } \\
\text { Karakteris } \\
\text { tiği } \\
\end{array}$ & 6 & 0 & 76 \\
\hline 37 & 2018 & MÖDAV & $\begin{array}{c}\text { Mehmet } \\
\text { ÖZBİRECİKLİ } \\
\text { İlker KIYMETLİ } \\
\text { ŞEN } \\
\end{array}$ & $\begin{array}{l}\text { Ethics Education And Vocailonal } \\
\text { Training Process Of Accounting } \\
\text { And Auditing Professions In } \\
\text { Turkey: A Historical Perspective }\end{array}$ & Derleme & Etik & 4 & 21 & 10 \\
\hline 38 & 2018 & MÖDAV & $\begin{array}{l}\text { İlkay ERTURAN } \\
\text { Emre ERGIN }\end{array}$ & $\begin{array}{l}\text { Dijital Denetim ve Dijital İkiz } \\
\text { Yöntemi }\end{array}$ & Kuramsal & $\begin{array}{l}\text { Denetimin } \\
\text { Geleceği }\end{array}$ & 5 & 6 & 23 \\
\hline 39 & 2018 & MÖDAV & Aziz DOĞAN & $\begin{array}{l}\text { Bağımsız Denetimde Yeni Bir } \\
\text { Yaklaşım: Kilit Denetim Konuları }\end{array}$ & Derleme & $\begin{array}{c}\text { Kilit } \\
\text { Denetim } \\
\end{array}$ & 20 & 3 & 21 \\
\hline 40 & 2018 & MÖDAV & Gökberk CAN & $\begin{array}{l}\text { A Descrıptıve Research On } \\
\text { Turkish Listed Manufacturıng } \\
\text { Companies’ Independent Audit } \\
\text { Characteristics }\end{array}$ & $\begin{array}{c}\text { Nicel } \\
\text { Araştırma }\end{array}$ & $\begin{array}{l}\text { Denetçi } \\
\text { Karakteris } \\
\text { tiği }\end{array}$ & 0 & 0 & 101 \\
\hline 41 & 2018 & MÖDAV & $\begin{array}{l}\text { Ayşegül CİĞER } \\
\text { Bülent KINAY }\end{array}$ & $\begin{array}{l}\text { Bağımsız Denetim Firmalarının } \\
\text { Bulut Bilişim Uygulamalarını } \\
\text { Benimseme Düzeylerine Yönelik } \\
\text { Nitel Bir Araştırma: Antalya İli } \\
\text { Örneği }\end{array}$ & $\begin{array}{c}\text { Nitel } \\
\text { Araştırma }\end{array}$ & $\begin{array}{l}\text { Denetimin } \\
\text { Geleceği }\end{array}$ & 0 & 4 & 23 \\
\hline 42 & 2018 & MÖDAV & Elda HOXHAJ & $\begin{array}{l}\text { IT Audit - Introduction Of The IT } \\
\text { Audit In An Organızation }\end{array}$ & Derleme & $\begin{array}{c}\text { Denetimin } \\
\text { Geleceği }\end{array}$ & 1 & 0 & 47 \\
\hline 43 & 2018 & MÖDAV & İlker CALAYOĞLU & $\begin{array}{l}\text { Muhasebe Ve Denetim Çevresinin } \\
\text { Değişimi Ve Bu Alanların } \\
\text { Öğretiminde Mesleki Yazılım } \\
\text { Kullanımının Tespit Edilmesi }\end{array}$ & $\begin{array}{c}\text { Nitel } \\
\text { Araştırma }\end{array}$ & Genel & 2 & 48 & 26 \\
\hline 44 & 2018 & MÖDAV & $\begin{array}{l}\text { Medine TÜRKCAN } \\
\text { Nalan AKDOĞAN }\end{array}$ & $\begin{array}{l}\text { Uluslararası Değerleme } \\
\text { Standartlarında Etik İlkeler Ve } \\
\text { Uluslararası Denetim Standartları } \\
\text { İle Karşılaştırmalı İncelenmesi }\end{array}$ & Teorik & Etik & 0 & 7 & 1 \\
\hline 45 & 2018 & MÖDAV & Erdal YILMAZ & $\begin{array}{l}\text { Bağımsız Denetimde Mesleki } \\
\text { Şüphecilik, Mesleki Şüpheciliğin } \\
\text { Ölçülmesi Ve Meslek Mensupları } \\
\text { Üzerinde Bir Araştırma }\end{array}$ & $\begin{array}{c}\text { Nicel } \\
\text { Araştırma }\end{array}$ & $\begin{array}{l}\text { Denetçi } \\
\text { Karakteris } \\
\text { tiği }\end{array}$ & 0 & 8 & 31 \\
\hline 46 & 2018 & MÖDAV & $\begin{array}{l}\text { Özlem ÖNER } \\
\text { Metin UYAR }\end{array}$ & $\begin{array}{l}\text { Vekâlet Teorisi Bağlamında } \\
\text { Denetim Faaliyetlerinin Ve } \\
\text { Kontrol Sistemlerinin Yönetim } \\
\text { Riskine Etkisi: Küçük Ve Orta } \\
\text { Boy İşletmelerde Bir Uygulama }\end{array}$ & $\begin{array}{c}\text { Nicel } \\
\text { Araştırma }\end{array}$ & $\begin{array}{c}\text { Risk } \\
\text { Odaklı } \\
\text { Denetim }\end{array}$ & 1 & 12 & 15 \\
\hline 47 & 2018 & MÖDAV & $\begin{array}{l}\text { Osman Nuri ŞAHİN } \\
\text { Şaban UZAY }\end{array}$ & $\begin{array}{l}\text { Bağımsız Denetimde Duygusal } \\
\text { Zeka: Bağımsız Denetçiler Üzerine } \\
\text { Bir Araştırma }\end{array}$ & $\begin{array}{c}\text { Nicel } \\
\text { Araştırma }\end{array}$ & $\begin{array}{c}\text { Denetçi } \\
\text { Karakteris } \\
\text { tiği } \\
\end{array}$ & 0 & 35 & 107 \\
\hline 48 & 2018 & MÖDAV & $\begin{array}{l}\text { Gökhan ÖZER } \\
\text { Mehmet GÜNLÜK } \\
\text { Kübra OKUTAN }\end{array}$ & $\begin{array}{l}\text { İç Ve Bağımsız Denetçiler } \\
\text { Arasındaki İlişkilerin, Üst Yönetim } \\
\text { Desteğinin Ve İç Denetimin } \\
\text { Bağımsızlığının İç Denetimin } \\
\text { Etkinliği Üzerindeki Etkileri } \\
\end{array}$ & $\begin{array}{c}\text { Nicel } \\
\text { Araştırma }\end{array}$ & $\begin{array}{c}\text { İç } \\
\text { Denetim }\end{array}$ & 0 & 31 & 50 \\
\hline 49 & 2018 & MÖDAV & Birsel SABUNCU & $\begin{array}{l}\text { İç Denetim Anlayışındaki } \\
\text { Değişiklikler ve Gelişmeler }\end{array}$ & Derleme & $\begin{array}{c}\text { İç } \\
\text { Denetim }\end{array}$ & 5 & 16 & 5 \\
\hline 50 & 2018 & MÖDAV & $\begin{array}{c}\text { Fatma } \\
\text { TEKTÜFEKÇİ }\end{array}$ & $\begin{array}{l}\text { Muhasebe ve Denetim } \\
\text { Ontolojisinde E-Dönüşüm Süreci } \\
\text { Kapsamındaki Dijital } \\
\text { Paradigmalara Teorik ve Felsefi } \\
\text { Açıdan Pragmatik Yaklaşım }\end{array}$ & $\begin{array}{c}\text { Nitel } \\
\text { Araştırma }\end{array}$ & $\begin{array}{l}\text { Denetimin } \\
\text { Geleceği }\end{array}$ & 4 & 37 & 4 \\
\hline
\end{tabular}




\begin{tabular}{|c|c|c|c|c|c|c|c|c|c|}
\hline 51 & 2018 & MÖDAV & $\begin{array}{l}\text { Recep GÜNEŞ } \\
\text { Hande } \\
\text { KAYGUSUZOĞLU }\end{array}$ & $\begin{array}{l}\text { Şirketlerdeki İç Kontrol Ve İç } \\
\text { Denetim Faaliyetlerine Ait } \\
\text { Rollerin Yöneticilerin Algıları } \\
\text { Üzerine Etkilerinin İncelenmesi: } \\
\text { Gaziantep, Kahramanmaraş Ve } \\
\text { Malatya İlleri Örneği }\end{array}$ & $\begin{array}{c}\text { Nicel } \\
\text { Araştırma }\end{array}$ & $\begin{array}{c}\text { İç } \\
\text { Denetim }\end{array}$ & 0 & 10 & 3 \\
\hline 52 & 2018 & MÖDAV & Azize ESMERAY & $\begin{array}{l}\text { Bilişim Teknolojisindeki } \\
\text { Gelişmelerin Muhasebe } \\
\text { Denetimine Katkısı }\end{array}$ & Derleme & $\begin{array}{l}\text { Denetimin } \\
\text { Geleceği }\end{array}$ & 6 & 16 & 16 \\
\hline 53 & 2018 & MÖDAV & Gönül İpek ALKAN & $\begin{array}{l}\text { Etik Teoriler Işığında Bağımsız } \\
\text { Denetim ve Bist'de Bir Araştırma }\end{array}$ & $\begin{array}{c}\text { Nitel } \\
\text { Araştırma }\end{array}$ & Etik & 1 & 34 & 14 \\
\hline 54 & 2018 & MÖDAV & $\begin{array}{c}\text { Beyhan MARŞAP } \\
\text { Bilge Leyli ELITAŞ } \\
\text { Zeki YANIK } \\
\text { Ayșenur ALTINAY }\end{array}$ & $\begin{array}{l}\text { Denetime Ahlak Felsefesi } \\
\text { Penceresinden Bir Bakış, Etik } \\
\text { Değerler Ve Faydacılık Çatışması } \\
\text { Üzerine Bir İnceleme }\end{array}$ & $\begin{array}{c}\text { Nicel } \\
\text { Araştırma }\end{array}$ & Etik & 1 & 12 & 1 \\
\hline 55 & 2018 & MÖDAV & $\begin{array}{l}\text { Seval SELİMOĞLU } \\
\text { Gül YEŞİLÇELEBİ }\end{array}$ & $\begin{array}{l}\text { Denetim Kültürünün Yeni Yol } \\
\text { Haritası: İş Dünyasındaki Yeni } \\
\text { Sistemlerle Bütünleșme }\end{array}$ & Teorik & $\begin{array}{l}\text { Denetimin } \\
\text { Geleceği }\end{array}$ & 0 & 12 & 8 \\
\hline 56 & 2018 & MÖDAV & $\begin{array}{l}\text { Kadir GÖKOĞLAN } \\
\text { Ahmet TANÇ }\end{array}$ & $\begin{array}{l}\text { Denetçi Bağımsızlığının } \\
\text { Denetimin Katma Değeri Üzerine } \\
\text { Etkisi }\end{array}$ & $\begin{array}{c}\text { Nicel } \\
\text { Araştırma }\end{array}$ & Genel & 0 & 6 & 25 \\
\hline 57 & 2018 & MÖDAV & $\begin{array}{l}\text { H. Pınar KAYA } \\
\text { Şaban UZAY }\end{array}$ & $\begin{array}{l}\text { Hileli Finansal Raporlama Ve } \\
\text { Bağımsız Denetçinin Sorumluluğu }\end{array}$ & Teorik & Etik & 1 & 36 & 3 \\
\hline 58 & 2018 & MÖDAV & Alexandru TRİFU & $\begin{array}{l}\text { The Audit Phılosophy, } \\
\text { Determınant For Firm Phılosophy }\end{array}$ & Derleme & $\begin{array}{l}\text { Denetimin } \\
\text { Geleceği }\end{array}$ & 0 & 0 & 15 \\
\hline 59 & 2018 & MÖDAV & Tuğçe BAYRAK & İç Denetim Felsefesi & Derleme & $\begin{array}{c}\text { İç } \\
\text { Denetim }\end{array}$ & 1 & 12 & 13 \\
\hline 60 & 2018 & MÖDAV & $\begin{array}{c}\text { Engin ERGÜDEN } \\
\text { A. Fatih DALKILIÇ } \\
\text { Can Tansel KAYA } \\
\text { A. R. Zafer SAYAR }\end{array}$ & $\begin{array}{l}\text { Finansal Raporlama Ve Denetim } \\
\text { Uygulamaları Kapsamında } \\
\text { Davranışsal Muhasebe Teorisine } \\
\text { Bakış }\end{array}$ & Derleme & $\begin{array}{l}\text { Denetçi } \\
\text { Karakteris } \\
\text { tiği }\end{array}$ & 2 & 11 & 37 \\
\hline 61 & 2019 & MÖDAV & $\begin{array}{l}\text { Nurten ERDOĞAN } \\
\text { Nurcan AZGIN }\end{array}$ & $\begin{array}{l}\text { Denetçinin Mesleki Şüpheciliğinin } \\
\text { Denetim Kalitesine Etkisi }\end{array}$ & $\begin{array}{c}\text { Nicel } \\
\text { Araştırma }\end{array}$ & $\begin{array}{l}\text { Bağımsız } \\
\text { Denetim } \\
\text { Kalitesi }\end{array}$ & 0 & 7 & 21 \\
\hline 62 & 2019 & MÖDAV & $\begin{array}{l}\text { Fatih Coşkun ERTAŞ } \\
\text { İbrahim ÇIDEM } \\
\text { Oktay ÖZKAN }\end{array}$ & $\begin{array}{l}\text { The Applicability Of Mandatory } \\
\text { Rotatıon Subjected By } \\
\text { Independent Auditors For } \\
\text { Members Of Accounting } \\
\text { Profession: A Research On } \\
\text { Certıfied Public Accountants In } \\
\text { Tokat }\end{array}$ & $\begin{array}{c}\text { Nicel } \\
\text { Araştırma }\end{array}$ & Genel & 0 & 8 & 14 \\
\hline 63 & 2019 & MÖDAV & $\begin{array}{l}\text { Nalan AKDOĞAN } \\
\text { F.Zehra MULUK }\end{array}$ & $\begin{array}{l}\text { Bağımsız Denetim Standartları } \\
\text { Kapsamında Grup Şirketlerinin } \\
\text { Önemlilik Düzeylerinin } \\
\text { Belirlenmesi, Kullanılan } \\
\text { Yöntemlerin İncelenmesi ve } \\
\text { Bayesian Modeli Uygulamasının } \\
\text { Değerlendirilmesi }\end{array}$ & $\begin{array}{c}\text { Nicel } \\
\text { Araştırma }\end{array}$ & $\begin{array}{c}\text { Risk } \\
\text { Odaklı } \\
\text { Denetim }\end{array}$ & 0 & 14 & 1 \\
\hline 64 & 2019 & MÖDAV & $\begin{array}{l}\text { Murat MAT } \\
\text { Servet ÖNAL }\end{array}$ & $\begin{array}{l}\text { Bağımsız Denetim Raporlarında } \\
\text { Denetim Görüşünü Etkileyen } \\
\text { Faktörlerin Belirlenmesi: Borsa } \\
\text { İstanbul İmalat Sanayi Sektörü } \\
\text { Şirketleri Üzerine Bir Uygulama }\end{array}$ & $\begin{array}{c}\text { Nicel } \\
\text { Araştırma }\end{array}$ & $\begin{array}{l}\text { Denetçi } \\
\text { Görüşüu }\end{array}$ & 0 & 11 & 28 \\
\hline 65 & 2019 & MÖDAV & Esra ATABAY & $\begin{array}{l}\text { Kurumsal Sürdürülebilirlik } \\
\text { Raporları ve Güvence Denetimi: } \\
\text { Türkiye'de GRI Rehberine Göre } \\
\text { Raporlama Yapan Firmalar } \\
\text { Üzerinde Bir Araştırma }\end{array}$ & $\begin{array}{c}\text { Nitel } \\
\text { Araştırma }\end{array}$ & $\begin{array}{l}\text { Güvence } \\
\text { Denetimi }\end{array}$ & 0 & 8 & 20 \\
\hline 66 & 2019 & MÖDAV & $\begin{array}{l}\text { Semra AKSOYLU } \\
\text { Onur TOK }\end{array}$ & $\begin{array}{l}\text { Muhasebe Denetiminde Bilgi } \\
\text { Teknolojilerinin Kullanımı } \\
\text { Üzerine Bir Araştırma }\end{array}$ & $\begin{array}{c}\text { Nicel } \\
\text { Araştırma }\end{array}$ & $\begin{array}{l}\text { Denetimin } \\
\text { Geleceği }\end{array}$ & 0 & 12 & 6 \\
\hline 67 & 2020 & MÖDAV & $\begin{array}{c}\text { Onur ÖZEVİN } \\
\text { Rahmi YÜCEL } \\
\text { Mehmet Akif ÖNCÜ }\end{array}$ & $\begin{array}{l}\text { Fraud Detecting With Benford's } \\
\text { Law: An Alternative Approach } \\
\text { With Bds And Critıc Values }\end{array}$ & $\begin{array}{c}\text { Nicel } \\
\text { Araştırma }\end{array}$ & $\begin{array}{l}\text { Benford } \\
\text { Yasası }\end{array}$ & 0 & 8 & 41 \\
\hline 68 & 2020 & MÖDAV & Ahmet ONAY & $\begin{array}{l}\text { Büyük Veri Çağında İç Denetimin } \\
\text { Dönüşümü }\end{array}$ & Derleme & $\begin{array}{c}\text { İç } \\
\text { Denetim }\end{array}$ & 0 & 2 & 21 \\
\hline 69 & 2020 & MÖDAV & $\begin{array}{l}\text { Yusuf TEPELİ } \\
\text { Burak KAYIHAN }\end{array}$ & $\begin{array}{l}\text { Firma Karakteristiklerinin Denetim } \\
\text { Firması Tercihi Üzerindeki } \\
\text { Etkisinin Analizi: Bist Şirketleri } \\
\text { Üzerine Bir Araştırma }\end{array}$ & $\begin{array}{c}\text { Nicel } \\
\text { Araştırma }\end{array}$ & Genel & 0 & 24 & 24 \\
\hline
\end{tabular}




\begin{tabular}{|c|c|c|c|c|c|c|c|c|c|}
\hline 70 & 2020 & MÖDAV & $\begin{array}{l}\text { Alp AYTAÇ } \\
\text { Ümit GÜCENME } \\
\text { GENÇOĞLU }\end{array}$ & $\begin{array}{l}\text { Key Audit Matters: A Perspectıve } \\
\text { Based On Biblıometric Analysis }\end{array}$ & $\begin{array}{c}\text { Nitel } \\
\text { Araştırma }\end{array}$ & $\begin{array}{c}\text { Kilit } \\
\text { Denetim }\end{array}$ & 0 & 18 & 33 \\
\hline 71 & 2020 & MÖDAV & $\begin{array}{l}\text { Seçil ÖZTÜRK } \\
\text { Sevim TASASIZ }\end{array}$ & $\begin{array}{l}\text { Türkiye’de Entegre Raporlama } \\
\text { Sürecinde İç Denetimin Rolü } \\
\text { Üzerine Bir Araştırma }\end{array}$ & $\begin{array}{c}\text { Nitel } \\
\text { Araştırma }\end{array}$ & $\begin{array}{c}\text { İç } \\
\text { Denetim }\end{array}$ & 0 & 5 & 9 \\
\hline 72 & 2020 & MÖDAV & $\begin{array}{l}\text { Aydın KARAPINAR } \\
\text { Tuğba DÖLEN }\end{array}$ & $\begin{array}{l}\text { Bağımsız Denetim Raporlarında } \\
\text { Kilit Denetim Konusu } \\
\text { Açıklamaları: Türkiye Örneği }\end{array}$ & $\begin{array}{l}\text { NicelAraşt } \\
\text { 1rma }\end{array}$ & $\begin{array}{c}\text { Kilit } \\
\text { Denetim }\end{array}$ & 0 & 10 & 14 \\
\hline 73 & 2020 & MÖDAV & $\begin{array}{c}\text { Gökhan ÖZER } \\
\text { A.Kürşat MERTER }\end{array}$ & $\begin{array}{l}\text { Denetim Komitesi Özelliklerinin } \\
\text { Finansal Raporlama Zamanlılığına } \\
\text { Etkisi: Bist’te Bir Uygulama }\end{array}$ & $\begin{array}{c}\text { Nicel } \\
\text { Araştırma }\end{array}$ & $\begin{array}{l}\text { Denetçi } \\
\text { Karakteris } \\
\text { tiği } \\
\end{array}$ & 0 & 9 & 15 \\
\hline 74 & 2016 & MDB & $\begin{array}{l}\text { Seval SELIMMOĞLU } \\
\text { Arzu ÖZSÖZGÜN } \\
\text { ÇALIŞKAN }\end{array}$ & $\begin{array}{l}\text { Sürdürülebilirlik Bağlamında } \\
\text { Uluslararası Güvence Denetimi } \\
\text { Standardı Gds (Isae) 3410-Sera } \\
\text { Gazı Beyanları-I }\end{array}$ & Derleme & $\begin{array}{l}\text { Güvence } \\
\text { Denetimi }\end{array}$ & 0 & 22 & 14 \\
\hline 75 & 2016 & MDB & $\begin{array}{l}\text { Murat KİRACI } \\
\text { Şafak AĞDENİZ }\end{array}$ & $\begin{array}{l}\text { İç Denetimde Örnekleme } \\
\text { Kullanımı: Kamu Sektöründe Satın } \\
\text { Alma Sürecinde Bir Uygulama }\end{array}$ & $\begin{array}{c}\text { Nitel } \\
\text { Araştırma }\end{array}$ & $\begin{array}{c}\text { İç } \\
\text { Denetim }\end{array}$ & 0 & 7 & 2 \\
\hline 76 & 2016 & MDB & Koray TUAN & $\begin{array}{l}\text { Denetim Komitesi Özellikleri Ve } \\
\text { İhtiyatlılık Arasındaki İlişki: Borsa } \\
\text { İstanbul Örneği }\end{array}$ & $\begin{array}{c}\text { Nicel } \\
\text { Araştırma }\end{array}$ & $\begin{array}{c}\text { Denetçi } \\
\text { Karakteris } \\
\text { tiği }\end{array}$ & 7 & 12 & 46 \\
\hline 77 & 2016 & MDB & $\begin{array}{l}\text { Burcu GÜROL } \\
\text { Tayfun } \\
\text { TÜYSÜZOĞLU }\end{array}$ & $\begin{array}{l}\text { Türkiye'de Kamu Yararını } \\
\text { İlgilendiren Kuruluşlar Nezdinde } \\
\text { Bağımsız Denetim Yapan Denetim } \\
\text { Kuruluşlarının Şeffaflık Raporları } \\
\text { Üzerinde Bir İnceleme }\end{array}$ & $\begin{array}{c}\text { Nitel } \\
\text { Araştırma }\end{array}$ & $\begin{array}{l}\text { Bağımsız } \\
\text { Denetim } \\
\text { Kalitesi }\end{array}$ & 0 & 10 & 2 \\
\hline 78 & 2016 & MDB & $\begin{array}{l}\text { Seval SELİMOĞLU } \\
\text { Arzu ÖZSÖZGÜN } \\
\text { ÇALIŞKAN }\end{array}$ & $\begin{array}{l}\text { Sürdürülebilirlik Bağlamında: } \\
\text { Uluslararası Güvence Denetimi } \\
\text { Standardı Gds (Isae) 3410-Sera } \\
\text { Gazı Beyanları -II }\end{array}$ & Derleme & $\begin{array}{l}\text { Güvence } \\
\text { Denetimi }\end{array}$ & 3 & 16 & 5 \\
\hline 79 & 2016 & MDB & $\begin{array}{l}\text { Suphi ASLANOĞLU } \\
\text { T.Derya BASKAN }\end{array}$ & $\begin{array}{l}\text { Denetçilerin Bağımsızlığının } \\
\text { Denetim Kalitesine Etkisi: Bist’de } \\
\text { Yapılan Bir Uygulama }\end{array}$ & $\begin{array}{c}\text { Nicel } \\
\text { Araştırma }\end{array}$ & $\begin{array}{c}\text { Bağımsız } \\
\text { Denetim } \\
\text { Kalitesi } \\
\end{array}$ & 0 & 27 & 6 \\
\hline 80 & 2016 & MDB & $\begin{array}{l}\text { Zafer SAYAR } \\
\text { A. Engin ERGÜDEN }\end{array}$ & $\begin{array}{l}\text { Son Düzenleme Ve Gelişmeler } \\
\text { Kapsamında Değişecek Ve } \\
\text { Yenilenecek Bağımsı Denetçi } \\
\text { Raporları }\end{array}$ & Derleme & $\begin{array}{l}\text { Denetim } \\
\text { Raporu }\end{array}$ & 10 & 7 & 5 \\
\hline 81 & 2016 & MDB & $\begin{array}{l}\text { Dursun ARIKBOĞA } \\
\text { Elçin } \\
\text { Şİ̧̇MANOĞLU }\end{array}$ & $\begin{array}{l}\text { Türkiye'de Bağımsız Denetimde } \\
\text { Mesleki Yargı Kullanımında } \\
\text { Karşılaşılan Sorunlar ve Çözüm } \\
\text { Önerileri }\end{array}$ & $\begin{array}{c}\text { Nicel } \\
\text { Araştırma }\end{array}$ & $\begin{array}{l}\text { Denetçi } \\
\text { Görüşü }\end{array}$ & 3 & 15 & 15 \\
\hline 82 & 2017 & MDB & Sezen ULUDAĞ & Değişen Risk Algısı ve İç Denetim & Derleme & $\begin{array}{c}\text { İç } \\
\text { Denetim }\end{array}$ & 2 & 9 & 3 \\
\hline 83 & 2017 & MDB & $\begin{array}{l}\text { Reşat KARCIOĞLU } \\
\text { Ersin KURNAZ }\end{array}$ & $\begin{array}{l}\text { Türkiye'nin Avrupa Birliği’ne } \\
\text { (AB) Üyelik Süreci Kapsamında } \\
\text { Kamu Sektöründe İç Denetim } \\
\text { Kültürü: Kamu İç Denetçilerine } \\
\text { Yönelik Bir Araştırma }\end{array}$ & $\begin{array}{l}\text { NicelAraşt } \\
\text { 1rma }\end{array}$ & $\begin{array}{c}\text { Risk } \\
\text { Odaklı } \\
\text { Denetim }\end{array}$ & 0 & 8 & 4 \\
\hline 84 & 2018 & MDB & $\begin{array}{l}\text { Yıldız ÖZERHAN } \\
\text { Banu } \\
\text { SULTANOĞLU }\end{array}$ & $\begin{array}{l}\text { Sürdürülebilirlik Raporu } \\
\text { Kapsamında Çevresel Bilgilerin } \\
\text { Raporlanması ve Güvence } \\
\text { Denetimi }\end{array}$ & $\begin{array}{c}\text { Nitel } \\
\text { Araştırma }\end{array}$ & $\begin{array}{l}\text { Güvence } \\
\text { Denetimi }\end{array}$ & 2 & 15 & 21 \\
\hline 85 & 2018 & MDB & $\begin{array}{l}\text { Engin DINÇ } \\
\text { Esra ATABAY }\end{array}$ & $\begin{array}{l}\text { Türkiye’deki Denetim } \\
\text { Literatürünün İçerik Analizi } \\
\text { (2007-2016) }\end{array}$ & $\begin{array}{c}\text { Nitel } \\
\text { Araştırma }\end{array}$ & Genel & 2 & 5 & 2 \\
\hline 86 & 2018 & MDB & $\begin{array}{c}\text { Seyhan ÇİL } \\
\text { KOÇYİĠT } \\
\text { Şükran GÜNGÖR } \\
\text { TANÇ } \\
\text { Bilge Leyli ELİTAŞ } \\
\end{array}$ & $\begin{array}{l}\text { İşletmenin Sürekliliği ve Bağımsız } \\
\text { Denetçi Raporlarının Türkiye } \\
\text { Bağımsız Denetim Standartları } \\
\text { (BDS570 ve BDS700) Açısından } \\
\text { İncelenmesi }\end{array}$ & $\begin{array}{c}\text { Nitel } \\
\text { Araştırma }\end{array}$ & $\begin{array}{l}\text { Denetim } \\
\text { Raporu }\end{array}$ & 4 & 20 & 1 \\
\hline 87 & 2018 & MDB & $\begin{array}{l}\text { Nalan AKDOĞAN, } \\
\text { Elif Senem GÜDÜ, } \\
\text { Ayşe IŞIK, İrem } \\
\text { SEVİNDİK, Derya } \\
\text { ŞAHİN, Gülşen } \\
\text { ÖZKAN } \\
\end{array}$ & $\begin{array}{l}\text { 2014-2016 Yılları Arasında Bist } \\
\text { Şirketleri İle İlgili Denetim } \\
\text { Görüşleri }\end{array}$ & $\begin{array}{c}\text { Nitel } \\
\text { Araştırma }\end{array}$ & $\begin{array}{l}\text { Denetçi } \\
\text { Görüşü }\end{array}$ & 5 & 4 & 0 \\
\hline 88 & 2018 & MDB & $\begin{array}{c}\text { Burcu ÖZGÜL } \\
\text { Banu TARHAN } \\
\text { MENGİ } \\
\end{array}$ & $\begin{array}{l}\text { İşletme Körlüğü Ve Çözüm } \\
\text { Önerisi Olarak Güvenilir } \\
\text { Danışman “İç Denetim”" }\end{array}$ & Derleme & $\begin{array}{c}\text { İç } \\
\text { Denetim }\end{array}$ & 3 & 34 & 15 \\
\hline
\end{tabular}




\begin{tabular}{|c|c|c|c|c|c|c|c|c|c|}
\hline 89 & 2018 & MDB & $\begin{array}{c}\text { Murat GÖRMEN } \\
\text { Mustafa SAVCI } \\
\text { Barış AYDEMİR }\end{array}$ & $\begin{array}{l}\text { Kamuda İç Denetim } \\
\text { Performansının Ölçümünde } \\
\text { Dengeli Başarı Göstergesi (DBG) } \\
\text { Yaklaşımının Değerlendirilmesi }\end{array}$ & Derleme & $\begin{array}{c}\text { İç } \\
\text { Denetim }\end{array}$ & 1 & 11 & 36 \\
\hline 90 & 2018 & MDB & Masum TÜRKER & $\begin{array}{l}\text { İşletmelerin Büyüme } \\
\text { Stratejilerinde Muhasebe-Denetim } \\
\text { Ekseninde Mali Kontrol ve } \\
\text { Yönetim }\end{array}$ & Derleme & Genel & 0 & 54 & 25 \\
\hline 91 & 2018 & MDB & Gözde BİRCAN & $\begin{array}{l}\text { İç Denetimde Kurumsal } \\
\text { Kültür Denetimi }\end{array}$ & Derleme & $\begin{array}{c}\text { İç } \\
\text { Denetim }\end{array}$ & 3 & 4 & 15 \\
\hline 92 & 2019 & MDB & $\begin{array}{l}\text { Nalan AKDÖĞÄN } \\
\text { Samet BÜLBÜL }\end{array}$ & $\begin{array}{l}\text { Bağımsız Denetçi Raporlarında } \\
\text { Kilit Denetim Konularının } \\
\text { Bildirilmesinde Bist } 100 \\
\text { Şirketlerindeki İlk Uygulama } \\
\text { Sonuçlarının Değerlendirmesine } \\
\text { Yönelik Bir Araştırma } \\
\end{array}$ & $\begin{array}{c}\text { Nitel } \\
\text { Araştırma }\end{array}$ & $\begin{array}{c}\text { Kilit } \\
\text { Denetim }\end{array}$ & 11 & 11 & 4 \\
\hline 93 & 2019 & MDB & $\begin{array}{l}\text { Nurten ERDOĞAN } \\
\text { Nurcan AZGIN }\end{array}$ & $\begin{array}{l}\text { Denetçilerin Denetim Kalitesine } \\
\text { Illişkin Teorik Algıları ve Pratikteki } \\
\text { Uygulamalarının Karşılaştırılması }\end{array}$ & $\begin{array}{c}\text { Nicel } \\
\text { Araştırma }\end{array}$ & $\begin{array}{l}\text { Bağımsız } \\
\text { Denetim } \\
\text { Kalitesi }\end{array}$ & 3 & 4 & 5 \\
\hline 94 & 2019 & MDB & $\begin{array}{l}\text { Mahmut Sami } \\
\text { ÖZTÜRK } \\
\text { Nazar Abdullah } \\
\text { SALEH }\end{array}$ & $\begin{array}{l}\text { Uluslararası İç Denetim } \\
\text { Standartları Kapsamında İç } \\
\text { Denetim Faaliyetlerinin } \\
\text { Değerlendirilmesi: Elektrik } \\
\text { Enerjisi Üretimi Yapan Bir } \\
\text { İşletmede Uygulama }\end{array}$ & $\begin{array}{c}\text { Nitel } \\
\text { Araştırma }\end{array}$ & $\begin{array}{c}\text { İç } \\
\text { Denetim }\end{array}$ & 0 & 1 & 9 \\
\hline 95 & 2019 & MDB & $\begin{array}{l}\text { Seval SELIMOĞLU } \\
\text { M.Hakan SALDI }\end{array}$ & $\begin{array}{l}\text { İşletmelerde Siber Risklerin } \\
\text { Analizinde, Haritalanmasında ve } \\
\text { Değerlendirilmesinde İç Denetimin } \\
\text { Rolü }\end{array}$ & Derleme & $\begin{array}{c}\text { İç } \\
\text { Denetim }\end{array}$ & 0 & 7 & 9 \\
\hline 96 & 2019 & MDB & $\begin{array}{l}\text { Esra ATABAY } \\
\text { Engin DİNÇ }\end{array}$ & $\begin{array}{l}\text { Türkiye Denetim Standartlarında } \\
\text { Adı Geçen Denetim Türlerinin } \\
\text { Genel Yapı Açısından } \\
\text { Karşılaştırılması }\end{array}$ & Derleme & Genel & 0 & 27 & 0 \\
\hline 97 & 2019 & MDB & $\begin{array}{l}\text { Mehmet DEMİR } \\
\text { Öznur ARSLAN }\end{array}$ & $\begin{array}{l}\text { Bağımsız Denetim Standartları } \\
\text { Açısından Hileye Karşı Denetçinin } \\
\text { ve Tarafların Sorumluluklarının } \\
\text { Bağımsız Denetçiler Yönünden } \\
\text { Değerlendirilmesi: Türkiye'deki } \\
\text { Bağımsız Denetçilere Yönelik Bir } \\
\text { Anket Çalışması }\end{array}$ & $\begin{array}{c}\text { Nicel } \\
\text { Araştırma }\end{array}$ & $\begin{array}{c}\text { Hile } \\
\text { Denetimi }\end{array}$ & 0 & 27 & 2 \\
\hline 98 & 2019 & MDB & $\begin{array}{c}\text { Günay Deniz } \\
\text { DURSUN } \\
\text { Rasim HACIOĞLU }\end{array}$ & $\begin{array}{l}\text { Sigorta Şirketlerinin İç Kontrol } \\
\text { Süreçlerinde İç Denetim } \\
\text { Faaliyetlerinin Etkinliğine Yönelik } \\
\text { Bir Model Önerisi }\end{array}$ & $\begin{array}{c}\text { Nitel } \\
\text { Araştırma }\end{array}$ & $\begin{array}{c}\text { İç } \\
\text { Denetim }\end{array}$ & 0 & 13 & 4 \\
\hline 99 & 2019 & MDB & $\begin{array}{l}\text { Hüseyin MERT } \\
\text { Memet GÜNER } \\
\text { Göktuğ DUYAR }\end{array}$ & $\begin{array}{l}\text { İşletmenin Sürekliliği Standardının } \\
\text { Denetim Raporlarına Etkilerinin } \\
\text { Bist Kapsamındaki Şirketler } \\
\text { Üzerinde Araştırılması } \\
\end{array}$ & $\begin{array}{c}\text { Nitel } \\
\text { Araştırma }\end{array}$ & $\begin{array}{l}\text { Denetim } \\
\text { Raporu }\end{array}$ & 2 & 7 & 8 \\
\hline 100 & 2019 & MDB & $\begin{array}{c}\text { Gulnur } \\
\text { SULTANKHANOVA } \\
\text { Serap YANIK } \\
\text { Yıldız AYANOĞLU } \\
\end{array}$ & $\begin{array}{l}\text { Sürdürülebilirlik Raporlarına } \\
\text { Verilen Güvence Beyanlarının } \\
\text { İçerik Analizi }\end{array}$ & $\begin{array}{c}\text { Nitel } \\
\text { Araştırma }\end{array}$ & $\begin{array}{l}\text { Güvence } \\
\text { Denetimi }\end{array}$ & 0 & 10 & 34 \\
\hline 101 & 2019 & MDB & $\begin{array}{c}\text { Birol YILDIZ } \\
\text { Şafak AĞDENİZ } \\
\end{array}$ & $\begin{array}{l}\text { Denetim 4.0'ın Teknolojik } \\
\text { Altyapıs1 }\end{array}$ & Derleme & $\begin{array}{l}\text { Denetimin } \\
\text { Geleceği }\end{array}$ & 0 & 16 & 13 \\
\hline 102 & 2019 & MDB & $\begin{array}{l}\text { Duygu KESKİN } \\
\text { Ebubekir } \\
\text { MOLLAAHMETOĞLU } \\
\text { Güneri GÖZÜAÇIK }\end{array}$ & $\begin{array}{l}\text { Kalite Güvence Mekanizması } \\
\text { Olarak Şeffaflık Raporları: } \\
\text { Türkiye'deki Bağımsız Denetim } \\
\text { Kuruluşlarına Yönelik Bir } \\
\text { Araştırma }\end{array}$ & $\begin{array}{c}\text { Nitel } \\
\text { Araştırma }\end{array}$ & Genel & 0 & 10 & 4 \\
\hline 103 & 2019 & MDB & $\begin{array}{l}\text { Merve ACAR } \\
\text { Hüseyin TEMIZ }\end{array}$ & $\begin{array}{l}\text { Denetçi Görüşlerinin Pay Senedi } \\
\text { Getirileri Üzerindeki Etkisi }\end{array}$ & $\begin{array}{c}\text { Nitel } \\
\text { Araștırma }\end{array}$ & $\begin{array}{l}\text { Denetçi } \\
\text { Görüşü }\end{array}$ & 0 & 2 & 44 \\
\hline 104 & 2020 & MDB & Nalan AKDOĞAN & $\begin{array}{l}\text { Borsa İstanbul(Bist) Şirketlerinin } \\
2017 \text { ve } 2018 \text { Yılllarındaki } \\
\text { Denetim Görüşleri İle Bağımsız } \\
\text { Denetçi Raporlarında Verilen } \\
\text { Görüšun Dayanağının } \\
\text { İncelenmesine Yönelik Bir } \\
\text { Araştırma }\end{array}$ & $\begin{array}{c}\text { Nitel } \\
\text { Araştırma }\end{array}$ & $\begin{array}{l}\text { Denetçi } \\
\text { Görüşü }\end{array}$ & 1 & 12 & 0 \\
\hline
\end{tabular}




\begin{tabular}{|c|c|c|c|c|c|c|c|c|c|}
\hline 105 & 2020 & MDB & Hüseyin MERT & $\begin{array}{l}\text { Muhasebe Ve Denetim Tezsiz } \\
\text { Yüksek Lisans Programlarının } \\
\text { Mesleki Gelişmeye Katkısı: Aday } \\
\text { Meslek Mensuplarına Yönelik Bir } \\
\text { Araştırma }\end{array}$ & $\begin{array}{c}\text { Nicel } \\
\text { Araştırma }\end{array}$ & Genel & 0 & 12 & 0 \\
\hline 106 & 2020 & MDB & Ömer Faruk GÜLEÇ & $\begin{array}{l}\text { Muhasebe Meslek Mensupları } \\
\text { Perspektifinden Bağımsız } \\
\text { Denetimde Kilit Denetim Konuları }\end{array}$ & $\begin{array}{c}\text { Nicel } \\
\text { Araştırma }\end{array}$ & $\begin{array}{c}\text { Kilit } \\
\text { Denetim }\end{array}$ & 0 & 11 & 10 \\
\hline 107 & 2020 & MDB & $\begin{array}{l}\text { S.Burak ARZOVA } \\
\text { Bertaç Şakir ŞAHİN }\end{array}$ & $\begin{array}{l}\text { Isa } 701 \text { (Bds 701) Kilit Denetim } \\
\text { Konular1: Bist 30, Bist } 50 \text { Ve Bist } \\
100 \text { Endekslerinde Yer Alan } \\
\text { Finans Kurumlarına Yönelik } \\
\text { Analiz }\end{array}$ & $\begin{array}{c}\text { Nicel } \\
\text { Araştırma }\end{array}$ & $\begin{array}{c}\text { Kilit } \\
\text { Denetim }\end{array}$ & 1 & 14 & 10 \\
\hline 108 & 2020 & MDB & $\begin{array}{l}\text { Selçuk BAKAN } \\
\text { Adem DURSUN }\end{array}$ & $\begin{array}{l}\text { Bilgisayar Destekli Denetim } \\
\text { Tekniklerinin Denetim Riskine } \\
\text { Etkileri: İstanbul'da Faaliyet } \\
\text { Gösteren Bağımsız Denetim } \\
\text { Kuruluşlarında Bir Uygulama }\end{array}$ & $\begin{array}{c}\text { Nicel } \\
\text { Araştırma }\end{array}$ & $\begin{array}{c}\text { Risk } \\
\text { Odaklı } \\
\text { Denetim }\end{array}$ & 0 & 14 & 11 \\
\hline 109 & 2020 & MDB & $\begin{array}{l}\text { Abdulaziz ERTAŞ } \\
\text { Tuğrul KANDEMİR }\end{array}$ & $\begin{array}{l}\text { Bağımsız Denetim Kapsamında } \\
\text { Türkiye'de Yapılan Yasal } \\
\text { Düzenlemelerin Bağımsız Denetim } \\
\text { Üzerine Etkileri }\end{array}$ & $\begin{array}{c}\text { Nicel } \\
\text { Araştırma }\end{array}$ & Genel & 0 & 13 & 0 \\
\hline 110 & 2020 & MDB & $\begin{array}{c}\text { Banu Tarhan MENGI } \\
\text { Sibel DOĞAN } \\
\text { Bengi AYRANCI } \\
\end{array}$ & $\begin{array}{l}\text { Değişim Yönetiminde İç } \\
\text { Denetçinin Rolü }\end{array}$ & Derleme & $\begin{array}{c}\text { İç } \\
\text { Denetim }\end{array}$ & 0 & 27 & 18 \\
\hline 111 & 2020 & MDB & Zekeriya DEMIR & $\begin{array}{l}\text { Covıd-19'un TFRS Kapsamındaki } \\
\text { Finansal Raporlamaya Olan } \\
\text { Etkileri ve TMS Kapsamında } \\
\text { Denetçinin Dikkate Alması } \\
\text { Gereken Hususların } \\
\text { Değerlendirilmesi } \\
\end{array}$ & Derleme & $\begin{array}{l}\text { Denetim } \\
\text { Raporu }\end{array}$ & 0 & 48 & 2 \\
\hline 112 & 2020 & MDB & Pınar DALOĞLU & $\begin{array}{l}\text { 1950’lerden 1980’lere Türk } \\
\text { Girişimcisinin Muhasebe Bilgisine } \\
\text { Verdikleri Önem ve Değişen } \\
\text { Dürüstlük Algısı Çerçevesinde } \\
\text { Denetim İlişkileri }\end{array}$ & Derleme & Genel & 0 & 34 & 3 \\
\hline 113 & 2016 & MUVU & $\begin{array}{l}\text { Haluk BENGÜ } \\
\text { Ece BERBER }\end{array}$ & $\begin{array}{l}\text { Kamu İç Denetim Faaliyetlerinin } \\
\text { Yönetilmesi, Plan Program } \\
\text { Hazırlama Aşamaları ve } \\
\text { Uygulaması }\end{array}$ & $\begin{array}{c}\text { Nitel } \\
\text { Araştırma }\end{array}$ & $\begin{array}{c}\text { İç } \\
\text { Denetim }\end{array}$ & 0 & 16 & 0 \\
\hline 114 & 2017 & MUVU & $\begin{array}{l}\text { Ekrem YILDIZ } \\
\text { Selim CENGİZ } \\
\text { Erdem BULUT }\end{array}$ & $\begin{array}{l}\text { Bağımsız Denetimde Beklenti } \\
\text { Boşluğu: Türkiye Araştırması }\end{array}$ & $\begin{array}{c}\text { Nicel } \\
\text { Araştırma }\end{array}$ & Genel & 0 & 4 & 16 \\
\hline 115 & 2018 & MUVU & $\begin{array}{l}\text { Cenk KIRITOĞLU } \\
\text { Mehmet } \\
\text { ÖZBİRECİKLİ }\end{array}$ & $\begin{array}{l}\text { Bağımsız Denetçilere Yönelik Etik } \\
\text { Eğitiminin Bağımsız Denetçilerin } \\
\text { Muhasebe Hilelerini } \\
\text { Algılamalarına Etkisi Üzerine Bir } \\
\text { Araştırma }\end{array}$ & $\begin{array}{c}\text { Nicel } \\
\text { Araştırma }\end{array}$ & Etik & 0 & 8 & 11 \\
\hline 116 & 2019 & MUVU & $\begin{array}{c}\text { Merve KIYMAZ } \\
\text { KIVRAKLAR } \\
\text { Ş.Doğuş DEMİRCI }\end{array}$ & $\begin{array}{l}\text { Benford Yasası'nın Mali Denetim } \\
\text { Alanında Kullanımı Üzerine Bir } \\
\text { Uygulama }\end{array}$ & $\begin{array}{c}\text { Nicel } \\
\text { Araştırma }\end{array}$ & $\begin{array}{l}\text { Benford } \\
\text { Yasası }\end{array}$ & 2 & 18 & 14 \\
\hline 117 & 2019 & MUVU & Melih ERDOĞAN & Denetim 4.0 Ve Ötesi & Teorik & $\begin{array}{l}\text { Denetimin } \\
\text { Geleceği }\end{array}$ & 3 & 1 & 14 \\
\hline 118 & 2020 & MUVU & $\begin{array}{c}\text { Züleyha } \\
\text { YILMAZ SOĞUKSU }\end{array}$ & $\begin{array}{l}\text { Muhasebe Denetiminde Dijital } \\
\text { Dönüşüm: Denetim Yazılımları }\end{array}$ & $\begin{array}{c}\text { Nitel } \\
\text { Araştırma }\end{array}$ & Genel & 0 & 27 & 19 \\
\hline 119 & 2020 & MUVU & $\begin{array}{l}\text { Zeynep } \\
\text { HATUNOGLU } \\
\text { Nurettin KOCA }\end{array}$ & $\begin{array}{l}\text { Denetim Firması Faaliyet Alanına } \\
\text { Göre Bağımsız Denetçinin, } \\
\text { Mesleki Bağlılık Ve Denetimde } \\
\text { Kalite Algı Düzeyi }\end{array}$ & $\begin{array}{c}\text { Nicel } \\
\text { Araştırma }\end{array}$ & $\begin{array}{l}\text { Bağımsız } \\
\text { Denetim } \\
\text { Kalitesi }\end{array}$ & 0 & 16 & 12 \\
\hline 120 & 2020 & MUVU & $\begin{array}{l}\text { Mahmut CAN } \\
\text { Seyhan ÇİL } \\
\text { KOÇYİĠi̇ }\end{array}$ & $\begin{array}{l}\text { BDS } 701 \text { Kilit Denetim } \\
\text { Konularının Bağımsız Denetçi } \\
\text { Raporunda Bildirilmesi Standardı } \\
\text { Uygulaması Üzerine Bir Araştırma }\end{array}$ & $\begin{array}{c}\text { Nicel } \\
\text { Araştırma }\end{array}$ & $\begin{array}{c}\text { Kilit } \\
\text { Denetim }\end{array}$ & 0 & 11 & 6 \\
\hline 121 & 2020 & MUVU & $\begin{array}{l}\text { Burak ÖZDOĞAN } \\
\text { Batuhan Fatih } \\
\text { MOLLAOĞULLARI }\end{array}$ & $\begin{array}{l}\text { Türkiye'de İç Denetim Ve } \\
\text { BağımsızDenetim İlişkisine } \\
\text { Yönelik Yapılan Lisansüstü Tez } \\
\text { Çalışmaları Üzerine Bir Araştırma }\end{array}$ & $\begin{array}{c}\text { Nitel } \\
\text { Araştırma }\end{array}$ & $\begin{array}{c}\text { İç } \\
\text { Denetim }\end{array}$ & 0 & 19 & 111 \\
\hline 122 & 2016 & MÇ & Sedat ERDOĞAN & $\begin{array}{l}\text { Bağımsız Denetçilerin Üçüncü } \\
\text { Kişilere Karşı İhmal } \\
\text { Kapsamındaki Sorumluluğu }\end{array}$ & Derleme & Genel & 0 & 13 & 18 \\
\hline
\end{tabular}




\begin{tabular}{|c|c|c|c|c|c|c|c|c|c|}
\hline 123 & 2016 & MÇ & Alpaslan YAŞAR & $\begin{array}{l}\text { Olumlu Görüş Dışındaki Denetim } \\
\text { Görüşlerinin Veri Madenciliği } \\
\text { Yöntemleriyle Tahminine İlişkin } \\
\text { Karar Ve Birliktelik Kuralları }\end{array}$ & $\begin{array}{c}\text { Nicel } \\
\text { Araştırma }\end{array}$ & $\begin{array}{l}\text { Denetçi } \\
\text { Görüşü }\end{array}$ & 6 & 12 & 33 \\
\hline 124 & 2016 & $\mathrm{MÇ}$ & Tuba ŞAVLI & $\begin{array}{l}\text { Türkiye’de Bağımsız Denetimde } \\
\text { Rotasyon: Düzenlemeler, } \\
\text { Uygulamalar ve Öneriler }\end{array}$ & Derleme & $\begin{array}{l}\text { Denetimin } \\
\text { Geleceği }\end{array}$ & 8 & 22 & 14 \\
\hline 125 & 2016 & MÇ & $\begin{array}{l}\text { Selim CENGİZ } \\
\text { Yusuf GÖR }\end{array}$ & $\begin{array}{l}\text { Kurumsal Yönetim Uygulamaları } \\
\text { ve Denetim Kalitesi Arasındaki } \\
\text { İlişki: Borsa İstanbul Kurumsal } \\
\text { Yönetim Endeksinde Bir } \\
\text { Araştırma }\end{array}$ & $\begin{array}{c}\text { Nicel } \\
\text { Araştırma }\end{array}$ & $\begin{array}{l}\text { Bağımsız } \\
\text { Denetim } \\
\text { Kalitesi }\end{array}$ & 0 & 21 & 17 \\
\hline 126 & 2017 & MÇ & $\begin{array}{l}\text { Zafer SAYAR } \\
\text { Muharrem } \\
\text { KARATAŞ }\end{array}$ & $\begin{array}{l}\text { Muhasebe ve Denetim Alanında } \\
\text { Yaşanan Son Gelişmeler İle } \\
\text { Muhasebe Mesleğinde Yeni } \\
\text { Trendler }\end{array}$ & Derleme & $\begin{array}{l}\text { Denetimin } \\
\text { Geleceği }\end{array}$ & 7 & 9 & 4 \\
\hline 127 & 2017 & $\mathrm{MÇ}$ & Selim CENGİZ & $\begin{array}{l}\text { Denetim Komitesi Etkinliğinin } \\
\text { Denetim Raporlarının Yayınlanma } \\
\text { Süresi Üzerindeki Etkisinin } \\
\text { İncelenmesi: Borsa İstanbul'da Bir } \\
\text { Uygulama }\end{array}$ & $\begin{array}{c}\text { Nicel } \\
\text { Araştırma }\end{array}$ & $\begin{array}{l}\text { Denetim } \\
\text { Raporu }\end{array}$ & 8 & 3 & 68 \\
\hline 128 & 2017 & $\mathrm{MÇ}$ & Kıvanç ERTİKİN & $\begin{array}{l}\text { Bağımsız Denetimde Bir Dönüm } \\
\text { Noktası: Enron Olayı ve Sarbanes } \\
\text { - Oxley Yasası }\end{array}$ & Derleme & Genel & 10 & 22 & 4 \\
\hline 129 & 2018 & $\mathrm{MÇ}$ & $\begin{array}{l}\text { Zeliha YILMAZ } \\
\text { Alpaslan YAŞAR }\end{array}$ & $\begin{array}{l}\text { Bağımsız Denetim Raporlarının } \\
\text { İşletmenin Sürekliliği Denetim } \\
\text { Standardı } 570 \text { Çerçevesinde } \\
\text { İncelenmesi: Bist İmalat Sanayi } \\
\text { Şirketleri Üzerine Bir Araştırma }\end{array}$ & $\begin{array}{c}\text { Nitel } \\
\text { Araştırma }\end{array}$ & $\begin{array}{l}\text { Denetçi } \\
\text { Görüşü }\end{array}$ & 0 & 13 & 12 \\
\hline 130 & 2018 & MÇ & Tamer AKSOY & $\begin{array}{l}\text { Risk Odaklı İç Denetim Sürecinde } \\
\text { Operasyonel Risklerin Belirlenip } \\
\text { Ölçülmesine Yönelik Uygulamalı } \\
\text { Bir 3x5 Risk Matriksi Ve Risk } \\
\text { Analiz Anket Formu Önerisi } \\
\end{array}$ & $\begin{array}{c}\text { Nitel } \\
\text { Araştırma }\end{array}$ & $\begin{array}{c}\text { İç } \\
\text { Denetim }\end{array}$ & 1 & 44 & 28 \\
\hline 131 & 2018 & MÇ & Şafak AĞDENİZ & $\begin{array}{l}\text { Entegre Raporlamada İç } \\
\text { Denetimin Rolü }\end{array}$ & Derleme & $\begin{array}{c}\text { İç } \\
\text { Denetim }\end{array}$ & 9 & 10 & 12 \\
\hline 132 & 2018 & $\mathrm{MÇ}$ & $\begin{array}{c}\text { Salih } \\
\text { KAYIKÇIOĞLU }\end{array}$ & $\begin{array}{l}\text { Şirketlerin İç Denetim } \\
\text { Birimlerinde Hile Denetimi ve Bir } \\
\text { Vaka İncelemesi }\end{array}$ & $\begin{array}{c}\text { Nitel } \\
\text { Araştırma }\end{array}$ & $\begin{array}{c}\text { İç } \\
\text { Denetim }\end{array}$ & 0 & 24 & 16 \\
\hline 133 & 2019 & MÇ & $\begin{array}{l}\text { Özkan SARISOY } \\
\text { Nazlı KEPÇE }\end{array}$ & $\begin{array}{l}\text { Bağımsız Denetim Raporunda } \\
\text { Kilit Denetim Konularına Yer } \\
\text { Verilmesi ve Beklenti Farkları }\end{array}$ & $\begin{array}{c}\text { Nicel } \\
\text { Araştırma }\end{array}$ & $\begin{array}{c}\text { Kilit } \\
\text { Denetim }\end{array}$ & 3 & 4 & 29 \\
\hline 134 & 2019 & MÇ & $\begin{array}{l}\text { Ayşegül CİĞER } \\
\text { Gizem ÇOPUR } \\
\text { VARDAR } \\
\text { Bülent KINAY } \\
\end{array}$ & $\begin{array}{l}\text { Bağımsız Denetçi Raporlarında } \\
\text { Yer Alan Kilit Denetim } \\
\text { Konularının Analizi: Borsa } \\
\text { İstanbul Örneği }\end{array}$ & $\begin{array}{c}\text { Nitel } \\
\text { Araştırma }\end{array}$ & $\begin{array}{c}\text { Kilit } \\
\text { Denetim }\end{array}$ & 4 & 6 & 34 \\
\hline 135 & 2019 & $\mathrm{MÇ}$ & $\begin{array}{l}\text { Hülya BOYDAŞ } \\
\text { HAZAR }\end{array}$ & $\begin{array}{l}\text { Bilgisayar Destekli Denetim Araç } \\
\text { ve Tekniklerinin Uygulanması }\end{array}$ & Teorik & Genel & 0 & 3 & 19 \\
\hline 136 & 2019 & $\mathrm{MÇ}$ & $\begin{array}{l}\text { M.Tevfik KARTAL } \\
\text { Neşe ÇOBAN } \\
\text { ÇELİKDEMİR }\end{array}$ & $\begin{array}{l}\text { İç Denetim Bölümlerinin } \\
\text { Organizasyonel Konumu: Ulusal } \\
\text { Ve Uluslararası Düzenlemeler } \\
\text { Çerçevesinde Türk Bankacılık } \\
\text { Sektörü Üzerine Karşılaştırmalı } \\
\text { Bir İnceleme }\end{array}$ & $\begin{array}{c}\text { Nitel } \\
\text { Araştırma }\end{array}$ & $\begin{array}{c}\text { İç } \\
\text { Denetim }\end{array}$ & 0 & 30 & 4 \\
\hline 137 & 2020 & $\mathrm{MÇ}$ & $\begin{array}{c}\text { Ömer Faruk GÜLEÇ } \\
\text { Aysun AKTAŞ } \\
\text { MOZEİKÇİ } \\
\end{array}$ & $\begin{array}{l}\text { Denetim Raporlarının Yayınlanma } \\
\text { Süresinin İncelenmesi: Bist } \\
\text { Şirketleri İçin Bir Uygulama }\end{array}$ & $\begin{array}{c}\text { Nicel } \\
\text { Araştırma }\end{array}$ & $\begin{array}{l}\text { Denetim } \\
\text { Raporu }\end{array}$ & 0 & 5 & 23 \\
\hline 138 & 2020 & MÇ & Özkan SARISOY & $\begin{array}{l}\text { 21. Yüzyılın Başında Bağımsız } \\
\text { Denetimdeki Gelişmeler: Yeni } \\
\text { Bağımsız Denetçi Raporunun } \\
\text { Ortaya Çıkışı }\end{array}$ & Derleme & $\begin{array}{l}\text { Denetim } \\
\text { Raporu }\end{array}$ & 0 & 15 & 34 \\
\hline 139 & 2020 & $\mathrm{MÇ}$ & Başak ERDEM & $\begin{array}{l}\text { Bağımsız Denetim Muafiyet } \\
\text { Eşiklerinin Yolsuzluk Endeksi } \\
\text { Üzerindeki Etkisi: Avrupa Birliği } \\
\text { Ülkelerinde Bir Analiz }\end{array}$ & $\begin{array}{c}\text { Nicel } \\
\text { Araştırma }\end{array}$ & Genel & 0 & 15 & 20 \\
\hline 140 & 2020 & MÇ & $\begin{array}{c}\text { Cengiz GÜNEY } \\
\text { Ahmet İÇÖZ }\end{array}$ & $\begin{array}{l}\text { Borsa İstanbul'da İşlem Gören } \\
\text { Şirketlere Yönelik "Şartlı Görüş" } \\
\text { İçeren Bağımsız Denetçi Raporları } \\
\text { Üzerine Bir İnceleme }\end{array}$ & $\begin{array}{c}\text { Nitel } \\
\text { Araştırma }\end{array}$ & $\begin{array}{l}\text { Denetçi } \\
\text { Görüşü }\end{array}$ & 0 & 15 & 0 \\
\hline
\end{tabular}


Muhasebe ve Finansman Dergisi - Temmuz 2021

(91): 57-80

\begin{tabular}{|c|c|c|c|c|c|c|c|c|c|}
\hline 141 & 2020 & MÇ & Neşegül PARLAK & $\begin{array}{l}\text { Muhasebe Denetimine İlişkin } \\
\text { Lisansüstü Tezlerin İncelenmesi }\end{array}$ & $\begin{array}{c}\text { Nitel } \\
\text { Araştırma }\end{array}$ & Genel & 1 & 11 & 0 \\
\hline 142 & 2020 & $\mathrm{MÇ}$ & $\begin{array}{c}\text { Süleyman YÜKÇÜ } \\
\text { Ömer AYDIN } \\
\text { Özlem } \\
\text { KOÇAKOĞLU }\end{array}$ & $\begin{array}{l}\text { Bağımsız Denetimde Dijital İkiz } \\
\text { Uygulaması }\end{array}$ & Derleme & $\begin{array}{l}\text { Denetimin } \\
\text { Geleceği }\end{array}$ & 0 & 16 & 12 \\
\hline 143 & 2020 & $\mathrm{MÇ}$ & N. Gözde BİRCAN & $\begin{array}{l}\text { Belirsizlik ve Kriz Durumlarında } \\
\text { Çevik Denetim Anlayışı ve } \\
\text { Denetim Mesleği Üzerine Etkileri: } \\
\text { Covı-19 Vakası Üzerine Bir } \\
\text { Değerlendirme }\end{array}$ & Derleme & $\begin{array}{c}\text { Risk } \\
\text { Odaklı } \\
\text { Denetim }\end{array}$ & 2 & 8 & 3 \\
\hline
\end{tabular}


